\title{
Effect of Inward Foreign Direct Investment on Income Inequality in Transition Countries
}

\author{
Bornali Bhandari \\ Fitchburg State College
}

\begin{abstract}
This paper empirically tests the link between FDI and income inequality for transitional countries in Eastern Europe and Central Asia for the period of 1990 to 2002. The theoretical motivation comes from a model developed in a previous paper, which predicts that inward FDI reduces income inequality for an economy where wage earners outnumber capital owners. Using fixed effects, there is no evidence that FDI inward stocks affect overall income inequality. However, breaking the effect into its components, the statistical evidence suggests that FDI inward stocks exacerbated wage income inequality, while reducing capital income inequality.
\end{abstract}

- JEL classification: F21, D31, O15

- Keywords: Development, Foreign Direct Investment, FDI, Globalization, Income Inequality, Transition Countries

"Globalization is Disequalizing."

Nancy Birdsall (2005)

\section{Introduction}

One of the current concerns in the arena of international development is the effect of globalization on income inequality. ${ }^{2}$ The argument is that globalization

\footnotetext{
*Corresponding address: Department of Social Sciences, Fitchburg State College, 160 Pearl Street, Fitchburg, MA 01420, USA. Tel: (978) 665-4855, Fax: (978) 665-4530, Email: bbhandari@fsc.edu. 
contributes to existing income inequality problems in developing countries. The intent in this paper is to empirically examine whether globalization especially Foreign Direct Investment (FDI), a key component of globalization, exacerbates income inequality problems in transitional countries.

Although FDI is perceived as an engine of economic growth, it can have other effects on countries like increasing wage inequality between skilled and unskilled workers or increasing regional inequality. ${ }^{3,4}$ Income inequality in this case is a good way to measure all dimensions of inequality. Not only does the concept of income cover both wage and rental income, it is a useful device to compare regional inequality.

The questions of determinants of FDI in transition economies [Holland and Pain (1998), Garibaldi et al. (2001)] and employment effects of FDI on transition economies [Hunya and Geischecker (2005)] have been discussed in the literature. There have been several papers in the literature to explain the rise in inequality in Eastern Europe including Aghion and Commander (1999), Ferreira (1999), Milanovic (1999), Garner and Terrell (1998), Yemtsov (2001) and Ivaschenko (2002). The literature has also looked at the impact of FDI on wage inequality including Bruno et al. (2004), who show that FDI increases wage inequality between skilled and unskilled workers in Hungary and Czech Republic but find no such evidence for Poland. However, the relationship between FDI and income inequality for the transition economies has not been examined yet.

A unique dataset of countries is used to examine the relationship between FDI and income inequality. The dataset includes transitional countries from Eastern Europe and former Soviet Union states. Nineteen transitional countries for the years 1990 to 2002 have been included in this study. They are Armenia, Azerbaijan, Bulgaria, Belarus, Czech Republic, Estonia, Georgia, Hungary,

\footnotetext{
${ }^{2}$ Bhagwati (2004; page3) defines economic globalization as "integration of national economies into the international economy through trade, direct foreign investment (by corporations and multinational companies), short-term capital flows, international flows of workers and humanity, and flows of technology".

${ }^{3}$ Extensive previous literature exists analyzing the impact of inward FDI on wage inequality on a variety of countries including Feenstra and Hanson (1997), Rodrik (1997), Harrison and Hanson (1999), Figlio and Blonigen (2000), Axarloglou et al. (2002) and Bruno et al. (2004).

${ }^{4}$ Anecdotal evidence from around the world shows that regional imbalances may have been created by the tendency of inward FDI in developing countries to go into specific regions. For example, proximity to European Union is an important determinant of inward FDI in Eastern Europe [Holland and Pain (1998)]. Further, only specific regions within these countries seem to have benefited from it.
} 
Kyrgyzstan, Lithuania, Latvia, Republic of Moldova, TFYR Macedonia, Poland, Romania, Russia, Slovak Republic, Slovenia and Ukraine. These countries are experiencing a transformation of their whole economic systems from planned economies to more market economies.

The first reason for choosing the transition countries is because of their unique experience. These countries opened their economies between 1989 and 1991, both politically and economically, giving us a natural experiment. There was an increase in both wage and income inequality immediately after, although the latter stabilized at a higher level after some time. Further, over the last ten years FDI inward stocks have increased to these countries. In Azerbaijan, FDI inward stocks as percentage of GDP reached $85.86 \%$ in $2002 .^{5}$

Secondly, the relationship between FDI and inequality has not been tested for transition economies. ${ }^{6}$ Bhandari (2006) shows evidence supporting that total FDI reduces income inequality overall for the U.S., a developed country. Borraz and López-Córdova (2004) find for Mexico, a developing country, that states which are more closely integrated with the rest of the world have more equal distribution of incomes and have exhibited larger declines in inequality because of increasing wages for women. ${ }^{7}$ Hanson (2005) finds that those states in Mexico which have higher exposure to globalization have experienced larger increase in incomes. Other developing countries for which the relationship between FDI and income inequality has been analyzed include South Korea [Mah (2002)] and China [Zhang and Zhang (2003) and Xing and Zhang (2004)]. Basu and Guraiglia (2003), Mahler et al. (1999) and Milanovic (2002) have studied the effect of FDI on income inequality using cross-sectional data.

The predictions of the theoretical model developed in Bhandari (2006) are tested for the transition countries. One of the main predictions of the model is that FDI reduces income inequality, given the initial condition that number of wage earners outnumber the number of capital owners.

These predictions are tested using data from nineteen transitional countries over the period 1990 to 2002. The main conclusion from this study is that there is no

\footnotetext{
${ }^{5}$ Author's calculations from UNCTAD FDI database.

${ }^{6}$ Yudaeva (2002) shows for the transition countries that the effect of trade regime liberalization on income inequality is dependent on the institutions existing in the country.

${ }^{7}$ States which are more closely related to the world means that states which have a higher number of people employed in foreign firms as a ratio to total unemployment. This is a measure of FDI in a state.
} 
evidence to support the hypothesis that FDI has exacerbated income inequality for transition countries. Rather the evidence from the econometric results show that FDI has no significant effect on income inequality for the transition economies for the period 1990 to 2002 .

However, the statistical analysis also finds that FDI has increased wage inequality significantly during the same period. The evidence for increasing wage inequality is consistent with previous literature, such as Bruno et al. (2004), Feenstra and Hanson (1997) and Harrison and Hanson (1999). Investigating further, I find that FDI is increasing average wages of the economy. This supports part of the economic theory which says that FDI increases the returns to labor.

The rest of the paper is organized in the following manner. Section II gives a background for the FDI and income inequality in Eastern Europe. Section III presents a brief description of the theoretical model. The econometric model is presented in Section IV. Section V presents the data description. Section VI presents the econometric results. Section VII discusses the results and explains the results in the previous section. The last section presents the conclusion of the paper.

\section{Background Information on FDI and Income Inequality in Transition Economies}

The Commonwealth of Independent States (CIS) and countries from the former Eastern Bloc experienced major transformations in their economic systems since the fall of the Iron Curtain. After an initial fall, per capita incomes rose, but so did inequality, unemployment, inflation and FDI inflows [De Melo et al. (1996), Ivaschenko (2002)].

The two variables of concern in this paper are income inequality and FDI inward stocks. In this paper, the Gini coefficient is used as a measure of income inequality, a common measure used in the literature. "The Gini coefficient is an area measure of the extent to which a Lorenz curve departs from the 45 degree line. The Lorenz curve captures all of the quintile share information for a given income distribution. The Lorenz curve lies below the 45 degree line". [Lambert (2001), pp. 24-27]. The Gini coefficient varies between 0 and 1. A larger Gini coefficient indicates higher inequality.

Graph 1 plots the average (of all nineteen countries) income inequality, wage inequality and FDI as a percentage of GDP from 1989 to 2002. It is evident from the graph that both income inequality and wage inequality have arisen, but wage inequality has increased more. Although FDI inward stocks to transition economies 
Graph 1: Average Income Inequality, Average Wage Inequality, Average FDI as a percentage of GDP, 1989-2002

Source: UNCTAD and World Income Inequality Database (WIID)

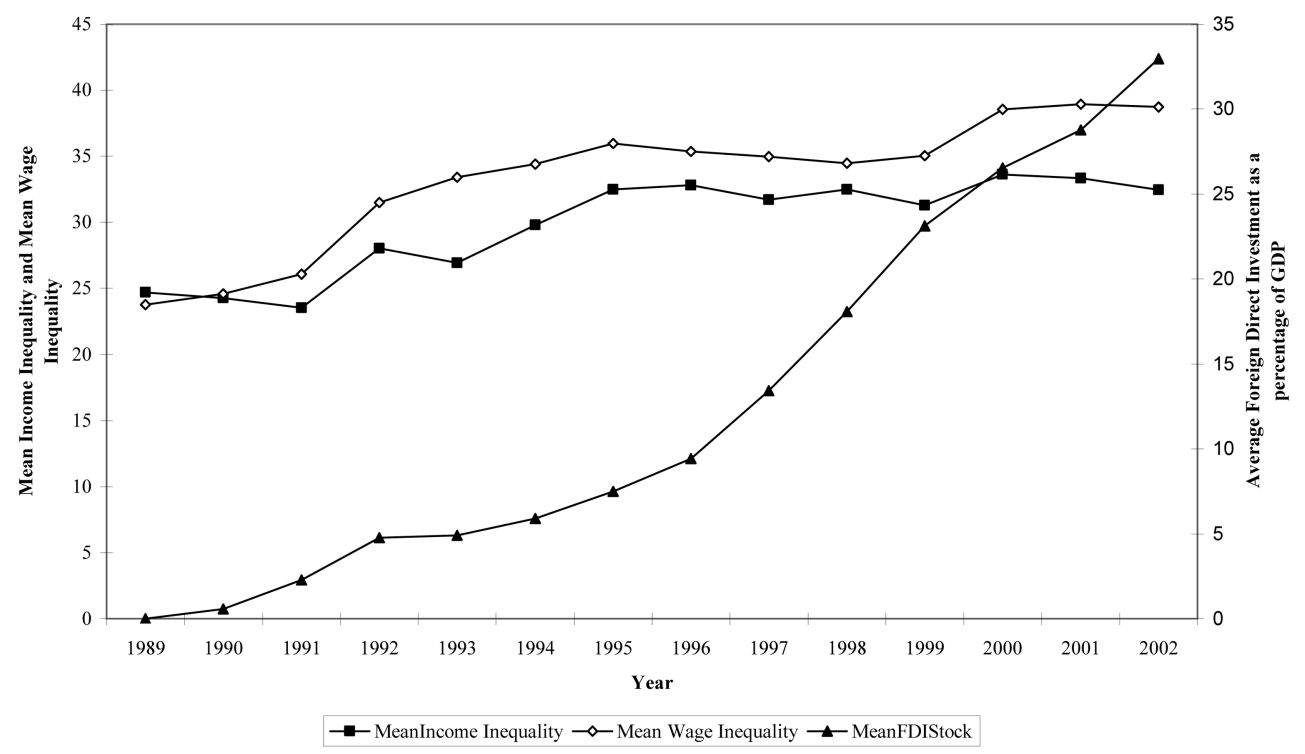

have not reached the levels of Asia, they have risen at a steady rate and reached a substantial proportion of GDP to make a significant impact on their local economies.

Graph 2 plots income inequality and Graph 3 plots wage inequality for the countries over the years 1989 to 2002 . The period has been divided into equal sub periods of 1989-1995 and 1996-2002 for purposes of illustration. With data from both the periods, it is evident that Georgia, Russia and Kyrgyzstan have experienced the largest increase in income inequality while Ukraine has experienced the largest decline. Wage inequality has increased in all the countries with the largest rise being experienced by Armenia, Azerbaijan, Georgia, Kyrgyzstan, Russia and Ukraine.

Graph 4 shows the increase in FDI inward stocks as a percentage of GDP for all the countries. Azerbaijan has received the highest FDI inward stocks followed by Estonia. ${ }^{8}$ The graph illustrates the uneven inflow of FDI into countries, also reported by (EBRD) European Bank for Reconstruction and Development Transition Report (2000). Also, it is only in the latter half of 1989-2002 that FDI inward stocks picked up in the region.

\footnotetext{
${ }^{8}$ Azerbaijan has received most of the FDI inward stock in the natural resources area especially oil. Oil is its number one export (CIA The World Factbook, March 2006).
} 
Graph 2: Income Inequality, 1989-2002, Source: WIID

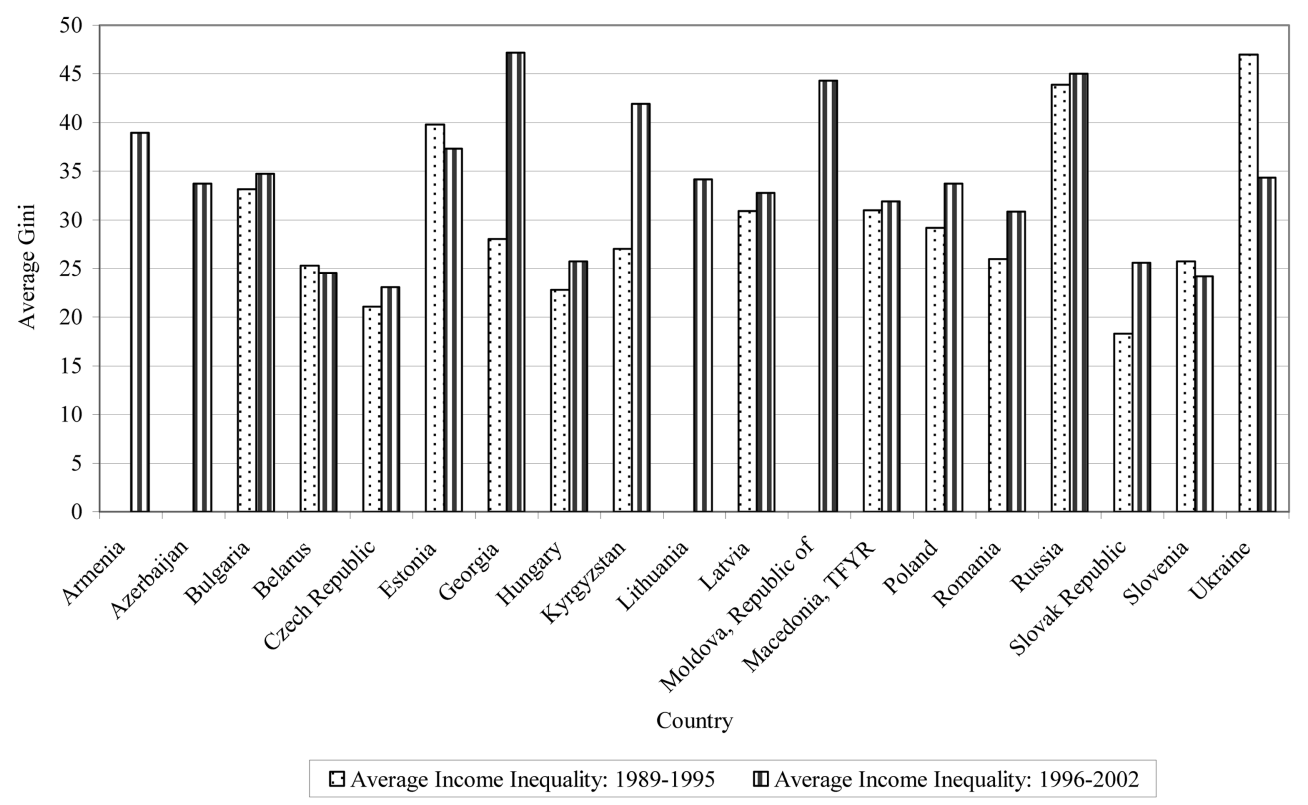

Graph 3: Wage Inequality: 1989:2002, Source: WIID

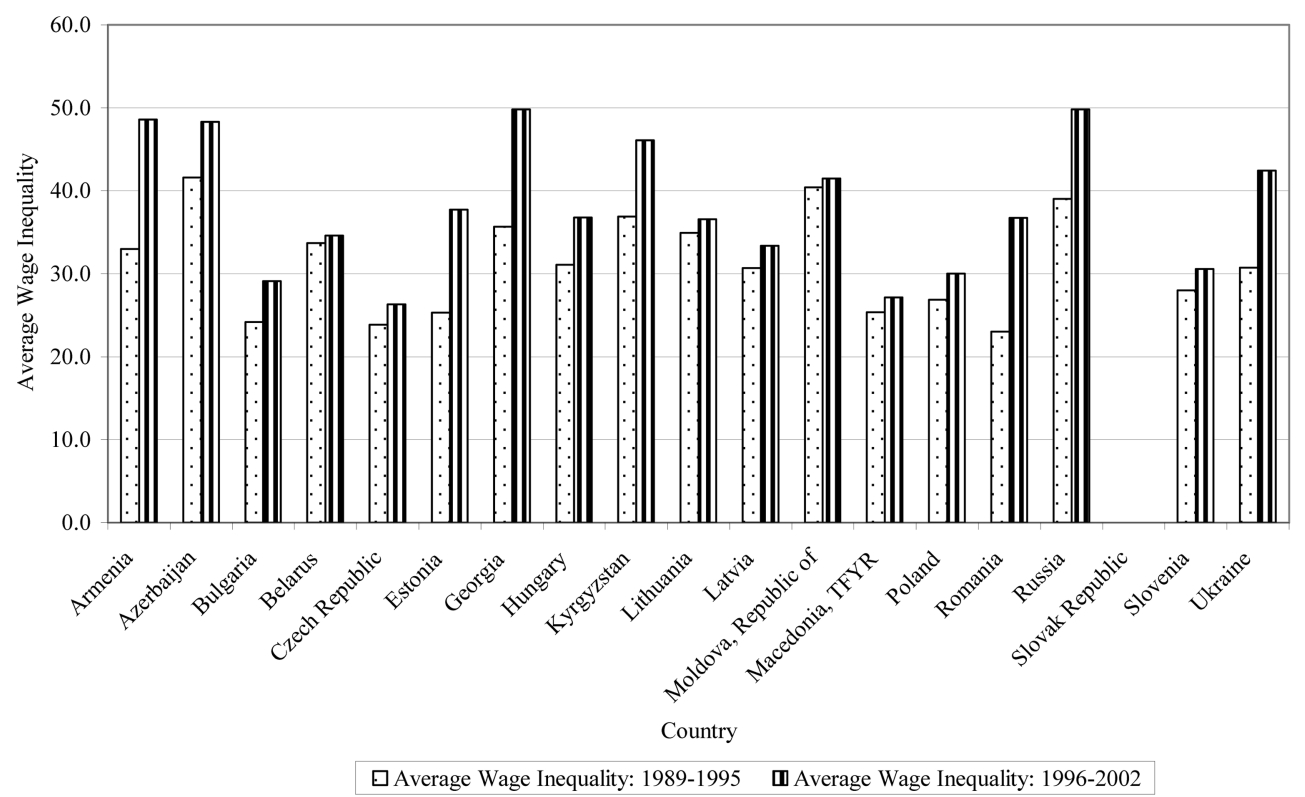

The European Bank for Reconstruction and Development (EBRD) Transition Report (2003) highlights some major trends for FDI in the transition countries.9 
Graph 4: FDI as a percentage of GDP, 1989:2002, Source: UNCTAD

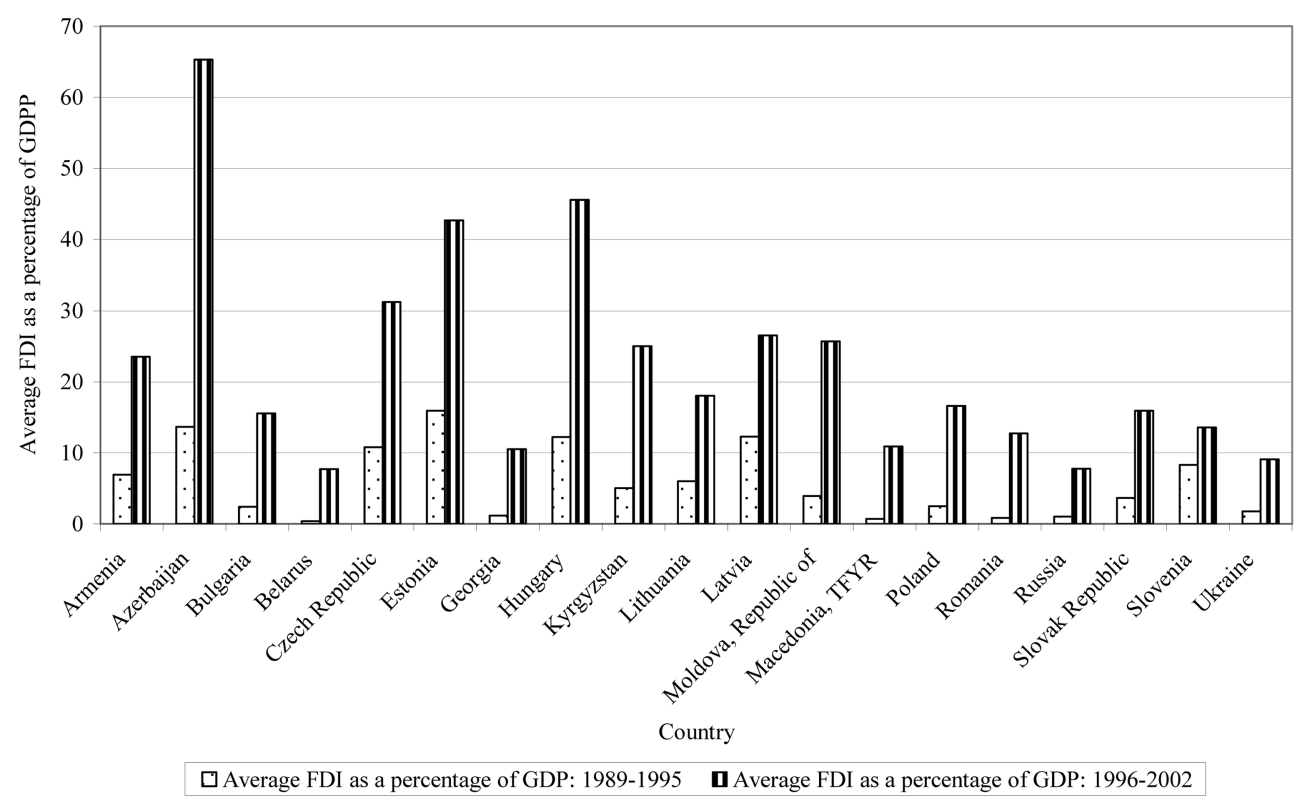

The EBRD Transition Report (2003) reports that the group of Central Eastern Group and Baltic States (CEB) constituting the Czech Republic, Estonia, Hungary, Latvia, Lithuania, Poland, the Slovak Republic and Slovenia have experienced the largest FDI inflows. Commonwealth of Independent States (CIS) including Armenia, Azerbaijan, Belarus, Georgia, Kyrgyz Republic (Kyrgystan), Moldova, Russia and Ukraine have experienced the next largest FDI inflows in the transition countries (EBRD Transition Report, 2003). ${ }^{10}$ The share of the latter has been increasing in the last few years (EBRD Transition Report, 2003).

The EBRD Transition Report (2003) further reports that Germany and Netherlands are the biggest investors in Eastern Europe. This especially holds true for the Czech Republic and Hungary where Germany and the Netherlands together account for more than $50 \%$ and $44 \%$ of FDI, respectively. The United States is the single largest investor in Russia and most of its investment in the region has been

${ }^{9}$ EBRD (2003), Paper 5.

${ }^{10}$ Kazakhstan, Turkmenistan and Uzbekistan also are a part of CIS but have been left out of this analysis because of lack of data. The Southern Eastern Europe (SEE) includes Albania, Bosnia and Herzegovina, Bulgaria, Croatia, FYR Macedonia, Romania and Serbia \& Montengro and has received the least FDI inward stock amongst the transition countries. 
directed towards Russia.

Most of the FDI inflows in the region have gone to manufacturing and general industry. Over the last three years, Russia has experienced sixteen percent of FDI inflows as a percentage of gross inflows going into the natural resources (EBRD Transition Report, 2003). Further, the data suggests that investment in CEB is relatively export-oriented, whereas investment in CIS substitutes for imports.

The EBRD Transition Report (2003) shows that the factors needed for a successful transition from a closed economy to an open economy are the same as the ones needed to attract FDI. Since Eastern Europe has been relatively successful in transforming their institutions at a relatively fast rate, they have also been successful in attracting FDI versus other transition countries. Other reasons why Eastern Europe has been so successful in attracting FDI include market size, geographical proximity to developed European countries, low unit labor costs, and supporting institutions.

Further interesting and relevant background information includes low intraregional FDI amongst the Eastern European countries (EBRD Transition Report, 2000), low degree of international orientation from foreign investors in Eastern Europe (EBRD Transition Report, 2000) and low labor mobility either between nations in Europe or within nations in Eastern Europe (EBRD Transition Report, 2003). ${ }^{11}$ Russia has made significant investment especially in CIS countries (EBRD Transition Report, 2000). Two motives for this include to secure themselves against domestic instability and to secure a share of natural resources exploration in the CIS (EBRD Transition Report, 2000). Not surprisingly, it is the oil and gas companies in Russia which are most globalized (EBRD Transition Report, 2000).

\section{Theoretical Model}

This section contains a description of the theoretical model from Bhandari (2006). ${ }^{12}$ The theoretical model begins with a closed economy of two factors of production and a single homogenous commodity produced using both labor and

\footnotetext{
${ }^{11}$ The EBRD Transition Report (2000) shows that that the median of the transnationality index is at 20 percent-calculated as the average of the ratios of foreign assets to total assets, foreign sales to total sales, and foreign employment to total employment. This is low versus the average of the index of multinational companies from other developing countries.
} 
capital. There are three agents in the economy, out of which two agents own equal amounts of labor (and have the same productivity) and one agent owns the capital in the economy. This is equivalent to the assumption that the numbers of wage earners outnumber the capital owner in the economy, which in turn implies that the capital owner is earning more than the labor owners. Other assumptions include no technological progress and full utilization of resources.

Optimizing in a partial equilibrium setup, the incomes of each consumer are derived. From those incomes, the income distribution of the economy is calculated. The next step is to open the economy and let exogenous foreign capital come in, which is then added to the domestic capital base. This increases the return to labor and lowers the return to capital and therefore closes the income gap between the two groups. Re-calculation of the income distribution in the open economy shows smaller income inequality.

One crucial assumption is that the initial numbers of wage earners outnumber the capital owners. Alternatively, if capital owners outnumber laborers, then FDI increases income inequality. However, this latter assumption seems unrealistic in the real world as the typical belief is that capital owners have higher incomes than laborers. Thus, the focus is on the hypothesis that FDI will reduce income inequality, provided wage earners outnumber capital earners.

The assumptions of the theoretical model fit well with the underlying structure of the Eastern European region. Since mobility of labor is low in Eastern Europe, there is no need to worry about labor moving from one region to another due to increased wages. Further, the foreign capital which comes into the region is external to the region as a whole and does not represent capital flows between the countries (with the exception of Russian investment in the natural resources area in CIS countries).

\section{Empirical Model}

The empirical model is adapted from the theoretical model to explain variations on income inequality over countries and time. The Gini coefficient is used as the dependent variable in the model. An increase in the Gini coefficient indicates an increase in income inequality and vice versa. Therefore, if an increase in a variable, ceteris paribus, results in an increase in the Gini coefficient, there will be a positive sign on the regression coefficient indicating a rise in the income inequality, and vice versa.

\footnotetext{
${ }^{12}$ Appendix 1 shows the details of the theoretical model from Bhandari (2006).
} 
Following the theory, FDI is included in the econometric model and predicted to have a negative coefficient with respect to income inequality. ${ }^{13}$ The control variables are divided in seven categories-macroeconomic, government policy, demographic, transition of political and socialinstitutions, structure of the economy, country dummies and the trend. ${ }^{14,15}$ This paper follows the literature [Bhandari (2006) and Wu et al. (2002)] in the inclusion of the control variables. Two additional categories of control variables are included for transition countries including political and social institutions and structures of the economy following Ivaschenko (2002).

The regression equation to be estimated is shown below in equation (1).

Income Inequality $_{i t}=$

$f\left(F_{i j}, G D P_{i t}, G D P S Q_{i t}, U R_{i t}, D I_{i t}, I N F L_{i t}, G G D P_{i t}, P O P 14_{i t}, P O P 65_{i t}, P V T_{i t}, I N D U S_{i t}, T_{\left.R E E_{i t}, T_{r e n d}\right)}\right.$

where, FDI=Foreign Direct Investment

GDP=Gross Domestic Product per capita

GDPSQ=Square of Gross Domestic Product per capita

$\mathrm{UR}=$ Unemployment Rate

$\mathrm{DI}=$ Domestic Investment as a proportion of GDP

\footnotetext{
${ }^{13}$ The economic theory dictates that initial income inequality should also be included in the empirical model. However, fixed effects (the estimation method used here) drops the initial income inequality variable. In the OLS model, it (the inequality in 1989 is equal to the initial income inequality) is positive and significant.

${ }^{14}$ Dr. Dreger (DIW Berlin), the discussant at the seventy-sixth Southern Economic Association conference seminar suggested controlling for the membership of the European Union. The dummy variable controlling for membership is dropped out of the fixed effects regression effectively not changing any of the results.

${ }^{15} \mathrm{An}$ anonymous referee suggested controlling for trade flows, political and social aspects of globalization akin to Dreher and Gaston (2006b). The political and social globalization variables are from Dreher and Gaston (2006a). Political Globalization includes measures of embassies in country, membership in international organizations and participation in UN Security Council Missions [Dreher and Gaston (2006a)]. Social Globalization includes measures on personal contact, information flows and cultural proximity [Dreher and Gaston (2006a)]. The measure for trade flows is taken from World Development Indicators CD-ROM and is measured as trade as a percentage of GDP. The empirical results do not change even after controlling for other aspects of globalization and trade flows i.e. FDI does not have an insignificant impact on income inequality. Further, the sample size is smaller because of unavailability of data for seven countries. In general, the results are similar to Dreher and Gaston (2006b) in the sense that there is no significant impact of overall globalization or various components of globalization on income inequality for a cross-section of countries. Therefore, other aspects of globalization are left out of the analysis in this paper. One interesting result from this analysis is that political globalization has a statistically significant impact on income inequality (using fixed effects). Ceteris paribus, a one percent increase in political globalization leads to a 0.11 percent decrease in income inequality.
} 


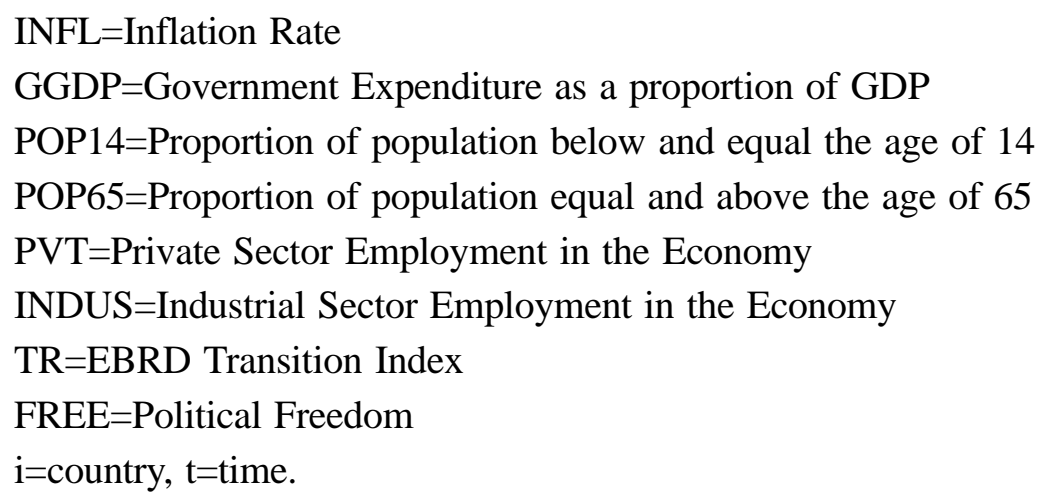

Gross Domestic Product (GDP) per capita, unemployment rates (UR), domestic investment spending and inflation rate are included as macroeconomic variables. It is hypothesized that GDP per capita, unemployment rate, domestic investment spending and inflation rate have an ambiguous, positive, negative and positive relationship with income inequality, respectively. Todaro (2004) contains a summary of the discussion on the Kuznets curve, which argues that GDP per capita (income) and income inequality have an inverted U-shaped relationship. The Kuznets curve shows that an initial increase in income is associated with increasing income inequality. With further increases in income, income inequality reaches a maximum and then starts declining. Therefore it is hypothesized that GDP per capita will have a positive sign and the square term of GDP per capita, a negative sign.

The intuitive reasoning behind the positive relationship between unemployment and income inequality is that increases in unemployment means more people without jobs or in other words lower incomes for families. Mocan (1999) shows that increase in structural unemployment will result in increasing income inequality.

The negative relationship between domestic investment spending and income inequality is explained by the intuition that increases in domestic investment spending means more people getting jobs, which implies that more people are earning, thereby putting a downward pressure on income inequality. Zhang and Zhang (2003) find that unequal domestic investment spending across the regions is the largest factor behind increasing regional inequality in China.

The expected positive relationship between inflation and income inequality (ceteris paribus) is explained by Ivaschenko (2002) who argues that an increase in the inflation rate will erode incomes especially for people whose nominal incomes are not adjusted with inflation, which then will lead to an increase in income inequality. Ferreira and Litchfield (1998) also find a positive impact of inflation on 
income inequality for Brazil.

Government expenditure as a percent of GDP is included as a government policy variable and the expected sign is negative. ${ }^{16}$ Intuitively, an increase in government expenditures will decrease income inequality, ceteris paribus. Government spending tends to increase income of all sections of the society especially the poorer sections, therefore decreasing the income inequality. ${ }^{17}$

The demographic variables consist of the proportion of people in a country below fifteen and the proportion of people above sixty-five years of age. ${ }^{18}$ People in this age group are dependent on the working population of the country and determine the dependency burden of the country. ${ }^{19}$ A higher dependency burden translates into lower incomes per capita or higher income inequality. ${ }^{20}$ Therefore, the expected sign on each variable is positive, ceteris paribus.

The structure of the economy constitutes two components; i.e. how much the economy is privatized and the composition of the economy in terms of industry, services and agriculture. The structure of the economy category includes the private sector employment in the economy and the industrial sector employment. The former is expected to have a positive impact on income inequality, ceteris paribus. Intuitively, the state before 1989-1991 would have employed the majority of the population giving everybody similar wages. With the transition, the share of the government decreases and the share of the private sector increases. The numbers of people released by the government sector are likely not to be fully absorbed by the private sector (Ivaschenko, 2002, and Milanovic, 1999). ${ }^{21}$ Further, the private sector gives wages based on worker productivity and therefore there will be a difference in wages received by the people employed in the private sector. Ferreira (1999) shows theoretically that privatization leads to increasing inequality

\footnotetext{
${ }^{16}$ Taxes which were included in the previous paper under this category are left out here because of lack of data availability.

${ }^{17} \mathrm{Wu}$ et al. (2002) has looked at the impact of various welfare measures which are aimed to reduce income inequality for the U.S.
${ }^{18}$ Education data are not available and therefore are not included in the model. However, the scarce data available indicates a very similar attainment rate for all countries. This is because of the structure of the economy with public schools before 1989 .

${ }^{19}$ Todaro (2004) discusses the age-dependency burden in general context.

${ }^{20}$ Recent studies for example Deaton and Paxson (1997) show that aging is leading to an increase in income inequality.
} 
due to changes in the wage structure and increased flexibility in the labor market.

Another change observed during the transition is that the sectoral composition of the economy changes. There has been massive de-industrialization in Eastern Europe. For example, the size of the industrial sector in Slovak Republic has come down from $59 \%$ in 1990 to $28 \%$ in $2002 .^{22}$ Ivaschenko (2002) argues that with deindustrialization, there is a move towards employment in services and the latter sector has typically higher wage differentials. Gustafsson and Johansson (1999) and Levy and Murnane (1992) have found a negative relationship between industrial sector employment and income inequality for developed countries. Therefore, one would expect a negative impact of the industrialization variable on income inequality, ceteris paribus.

The last category of control variables measures the transition, including the transition index and political freedom. The Transition index measures the liberalization of markets, institutions and infrastructure. Although under ideal circumstances liberalization should lead to lower inequality, it is difficult to predict the sign on the variable. Initially the countries may experience some rise in inequality because of the fall of the state sector and state managed prices. As for political freedom, Gradstein et al. (2001) and Rodrik (1999) argue that it will lead to increased income equality. On the other hand, Dreher and Gaston (2006b) predict that democracy promotes equality based on the political science literature. ${ }^{23}$ Therefore, the prediction is that political freedom variable has an ambiguous impact on income inequality.

Table 1 presents the control variables and their expected signs.

\section{Data Description}

This section contains a brief description of variables used in the paper. Appendix 2 contains data definition and sources. Data were collected for the nineteen

\footnotetext{
${ }^{21}$ Milanovic (1999) shows that a change in the composition of employment from the state sector to either the rich private sector or the unemployed sector can result in increasing inequality.

${ }^{22}$ World Development Indicators CD-ROM, 2005.

${ }^{23}$ Dreher and Gaston (2006b) control for democracy while looking at the impact of globalization on income inequality and do not find any significant results. This democracy variable is different than the political globalization component in their analysis. The results of Dreher and Gaston (2006b) are broadly similar to this paper regarding political freedom.
} 
Table 1. Variables and Expected Signs

\begin{tabular}{lc}
\hline \multicolumn{1}{c}{ Variables } & Expected Signs \\
\hline FDI & - \\
Real GDP per capita & + \\
Real GDP per capita square & - \\
Domestic Investment Spending & - \\
Unemployment Rate & + \\
Inflation Rate & + \\
Government Expenditure & - \\
Proportion of Population below age 14 & + \\
Proportion of Population above age 65 & + \\
Private Sector Employment & + \\
Share of Industrial Sector Employment & - \\
EBRD Transition Index & Ambiguous \\
Political Freedom & Ambiguous \\
\hline
\end{tabular}

countries mentioned above from 1990 to $2002 .{ }^{24}$ The dataset is unbalanced.

The first variable to be discussed is the income inequality Gini coefficient. The source of the data is the World Income Inequality Database, Version 2.0 (WIID2a), which has collected such data from Transmonee $2004 .{ }^{25}$ The income inequality variable is calculated using Disposable Income data. All people are surveyed and the income sharing unit is the household. Another measure for income inequality available from WIID2a is Gini coefficients calculated using data on Gross Earnings. I use this as a measure of wage inequality. This is because these surveys only cover employed people. Further, the income sharing unit is a person.

Inward FDI stock as a percentage of GDP is used as a measure of FDI. The data are available from UNCTAD from 1990 in millions of dollars. The stock measure is used because it fits in with the assumption of the theoretical model, where foreign capital comes in exogenously and is used together with domestic capital to produce a product.

It is difficult to get measures of both Private Sector Employment and Industrial

\footnotetext{
${ }^{24} \mathrm{FDI}$ data for 1989 were unavailable and therefore that year was left out. Other South East European countries including Albania and components of Yugoslavia were left out because of lack of data.

${ }^{25}$ I have tried to be as consistent as possible making sure that most of the data comes from Transmonee with unit of analysis, income sharing unit and definition being the same.
} 
Sector Employment. Therefore, similar to Ivaschenko (2002), share of private sector in GDP from EBRD Transition Reports is used here. For the share of industry, following Ivaschenko (2002), I use the value added by industry as a percentage of GDP. ${ }^{26}$

The transition of Eastern Europe is measured by the EBRD transition index. It is an average of nine measures of transition including index of price liberalization, index of foreign exchange and trade liberalization, index of small-scale privatization, index of large-scale privatization, index of enterprise reform, index of competition policy, index of banking sector reform, index of non-banking sector reform and index of infrastructural reform. It varies from one to four with one indicating that the economy is closed.

The political freedom variable is collected from Freedom House. It is an average of two indices including political rights and civil liberties. It varies from one to seven with seven indicating that that the country has neither of the two freedoms. This means that if the political freedom variable is falling, freedom is therefore increasing. Therefore, if income inequality falls due to increase in political freedom one would expect a positive sign.

Table 2 and Table 3 display the summary statistics and correlation coefficients.

\section{Econometric Results}

The results are presented using the Income inequality and FDI inward stocks from UNCTAD. All the variables are in log form. Therefore, the coefficients can be read as elasticities. The econometric model is estimated using Ordinary Least Squares corrected for heteroscedasticity and fixed effects. ${ }^{27,28}$ The results are reported in Table $4 .{ }^{29}$

There is little evidence in these data to support the hypothesis that income

\footnotetext{
${ }^{26}$ The percentage of people employed in industry is available. However, it suffers from missing observations and 2002 data are completely unavailable.

${ }^{27}$ The Hausman test supports usage of fixed effects over both panel data and random effects.

${ }^{28}$ Income inequality is tested as a possible determinant of FDI and is found to be statistically insignificant. Further, the instrumental variable method with Fixed Effects using lagged FDI as an instrument shows that the results are very similar to the fixed effects Model. The results are reported in the third column of Table 4. Campos and Kinoshita (2003) who examine the determinants of FDI in Transition Economies between 1990 and 1998 do not include income inequality in their analysis. Therefore, it is fair to conclude that the results are not biased due to endogeneity and is not an issue in this analysis.
} 
Table 2. Summary Statistics

\begin{tabular}{|c|c|c|c|c|c|}
\hline $\log ($ Variable $)$ & Mean & Std. Dev. & Min & Max & Observations \\
\hline Income Inequality & 3.419956 & 2335177 & 2.890372 & 3.918005 & $\mathrm{~N}=151$ \\
\hline Wage Inequality & 3.527188 & .2222704 & 3.015535 & 3.953165 & $\mathrm{~N}=159$ \\
\hline FDI & 2.096986 & 1.599758 & -10.55358 & 4.452724 & $\mathrm{~N}=208$ \\
\hline GDP per capita & 8.573394 & .684284 & 7.106288 & 9.783328 & $\mathrm{~N}=241$ \\
\hline EBRD Index & .8435175 & .3844339 & 0 & 1.348361 & $\mathrm{~N}=247$ \\
\hline Inflation & 3.418507 & 1.909244 & -2.922487 & 9.644866 & $\mathrm{~N}=228$ \\
\hline Unemployment & 1.877311 & 1.171933 & -2.995732 & 3.983413 & $\mathrm{~N}=210$ \\
\hline Govt. Expenditure & 2.825615 & .3205186 & 1.738757 & 3.405335 & $\mathrm{~N}=244$ \\
\hline Freedom & .9984676 & .4754802 & 0 & 1.791759 & $\mathrm{~N}=235$ \\
\hline Share Industry & 3.540399 & .2399425 & 2.073744 & 4.096323 & $\mathrm{~N}=246$ \\
\hline Domestic Industry & 3.115109 & .4030016 & .4893516 & 4.090516 & $\mathrm{~N}=245$ \\
\hline Share Private & 3.750641 & .6117201 & 1.609438 & 4.382027 & $\mathrm{~N}=229$ \\
\hline Share Pop. $<=14$ & 3.077911 & .2059103 & 2.70805 & 3.626184 & $\mathrm{~N}=247$ \\
\hline Share Pop. $>=60$ & 2.393451 & .2834528 & 1.571772 & 2.772589 & $\mathrm{~N}=247$ \\
\hline CPI & 3.646025 & 1.843709 & -7.011445 & 5.436677 & $\mathrm{~N}=204$ \\
\hline Avg. Wage & 8.405357 & 3.170662 & .0953102 & 15.48709 & $\mathrm{~N}=175$ \\
\hline Share Services & 3.822867 & .3214613 & 1.514128 & 4.26268 & $\mathrm{~N}=246$ \\
\hline Exchange Rate & 3.327685 & 2.602224 & -3.093897 & 10.40593 & $\mathrm{~N}=191$ \\
\hline Trade & 4.51 & 0.37 & 3.27 & 5.25 & $\mathrm{~N}=244$ \\
\hline $\begin{array}{l}\text { Secondary School } \\
\text { Enrollment }\end{array}$ & 2.17 & 0.23 & 1.76 & 2.59 & $\mathrm{~N}=74$ \\
\hline $\begin{array}{l}\text { Labor Force } \\
\text { Secondary Education }\end{array}$ & 4.00 & 0.32 & 1.97 & 4.37 & $\mathrm{~N}=80$ \\
\hline Productivity & 13.93 & 0.68 & 12.50 & 15.09 & $\mathrm{~N}=241$ \\
\hline Real Interest Rate & 2.15 & 1.15 & -2.50 & 5.93 & $\mathrm{~N}=131$ \\
\hline
\end{tabular}

inequality is affected by FDI. The simple OLS result does suggest that FDI reduces income inequality but this turns out to be an incorrect inference once one is more careful to control for fixed effects. The fixed effects model is more credible and is therefore used for the rest of the analysis.

Using the fixed-effects estimates for interpretation, a one percent increase in FDI

\footnotetext{
${ }^{29}$ Using the Arellano-Bond estimator, I find that FDI increases income inequality significantly. The coefficient on FDI is 0.03 and t-stat is 1.53 . There are 87 observations and 15 groups in the regression. This would mean that ceteris paribus, one percent increase in FDI is increasing income inequality by 0.03 percent.
} 
Table 3. Correlation Matrix

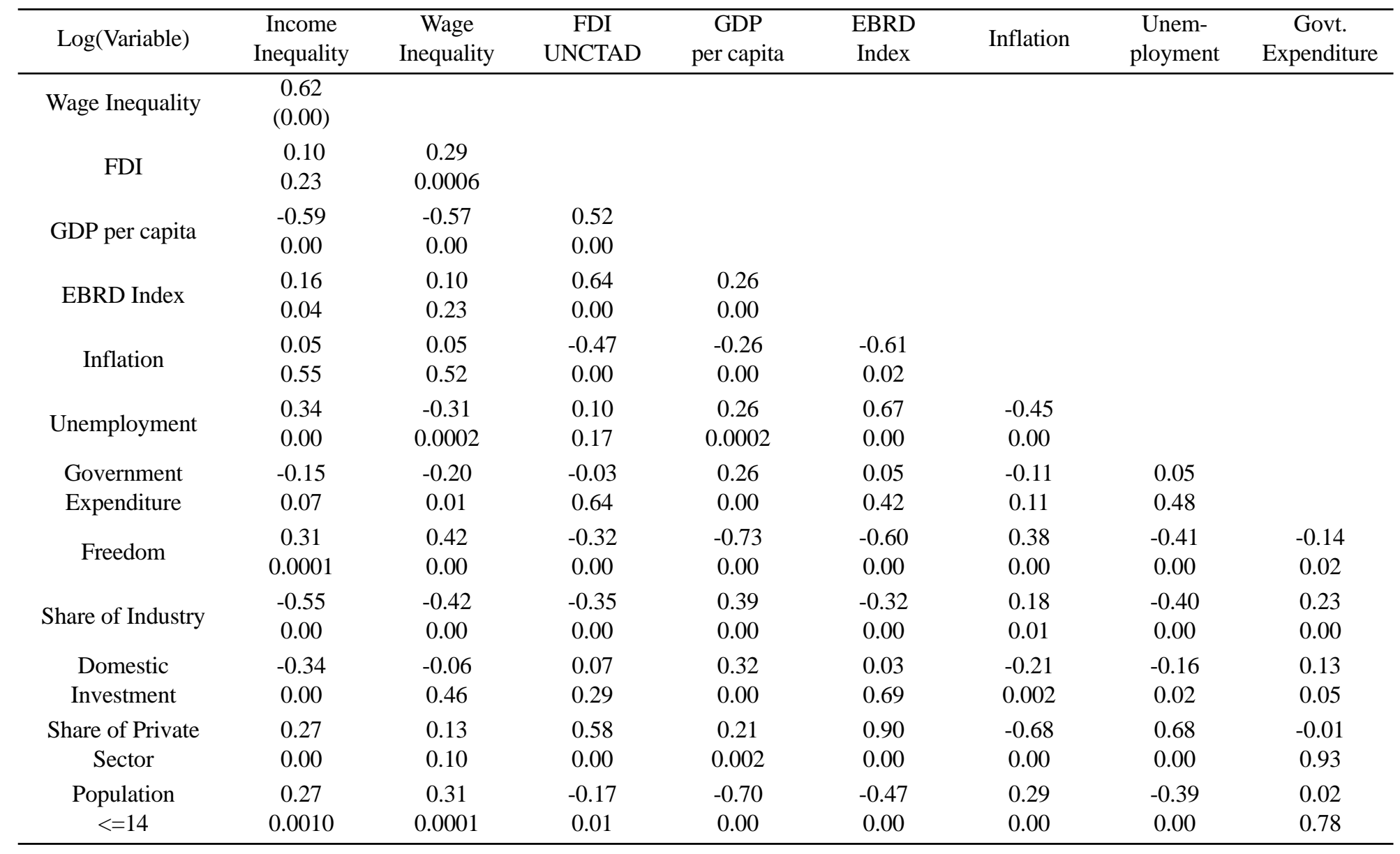


Table 3. Contined.

\begin{tabular}{|c|c|c|c|c|c|c|c|c|}
\hline $\log ($ Variable $)$ & $\begin{array}{l}\text { Income } \\
\text { Inequality }\end{array}$ & $\begin{array}{c}\text { Wage } \\
\text { Inequality }\end{array}$ & $\begin{array}{c}\text { FDI } \\
\text { UNCTAD }\end{array}$ & $\begin{array}{c}\text { GDP } \\
\text { per capita }\end{array}$ & $\begin{array}{l}\text { EBRD } \\
\text { Index }\end{array}$ & Inflation & $\begin{array}{l}\text { Unem- } \\
\text { ployment }\end{array}$ & $\begin{array}{c}\text { Govt. } \\
\text { Expenditure }\end{array}$ \\
\hline \multirow{2}{*}{$\begin{array}{l}\text { Population } \\
>=65\end{array}$} & -0.23 & -0.28 & 0.04 & 0.63 & 0.40 & -0.19 & 0.36 & -0.04 \\
\hline & 0.02 & 0.05 & 0.58 & 0.00 & 0.00 & 0.004 & 0.00 & 0.52 \\
\hline \multirow{2}{*}{ CPI } & -0.00 & 0.10 & 0.65 & 0.05 & 0.71 & -0.68 & 0.47 & -0.03 \\
\hline & 1.00 & 0.24 & 0.00 & 0.45 & 0.00 & 0.00 & 0.00 & 0.61 \\
\hline Average Wage & -0.34 & -0.10 & 0.04 & 0.39 & 0.33 & -0.18 & -0.12 & -0.31 \\
\hline Share of Services & 0.50 & 0.04 & 0.00 & 0.00 & 0.00 & 0.00 & 0.00 & 0.001 \\
\hline \multirow{2}{*}{ Exchange Rate } & -0.36 & 0.06 & 0.18 & -0.05 & -0.11 & -0.03 & -0.27 & -0.42 \\
\hline & 0.00 & 0.51 & 0.02 & 0.51 & 0.13 & 0.64 & 0.00 & 0.00 \\
\hline \multirow{2}{*}{ Trade } & -0.16 & 0.10 & 0.39 & 0.10 & 0.24 & -0.06 & -0.0001 & 0.30 \\
\hline & 0.04 & 0.19 & 0.00 & 0.12 & 0.00 & 0.35 & 0.9993 & 0.00 \\
\hline $\begin{array}{l}\text { Labor Force } \\
\text { Secondary School }\end{array}$ & 0.00 & 0.00 & 0.16 & 0.00 & 0.13 & 0.87 & 0.0002 & 0.51 \\
\hline \multirow{2}{*}{ Productivity } & -0.59 & -0.57 & 0.08 & 0.99 & 0.30 & -0.29 & 0.29 & 0.27 \\
\hline & 0.00 & 0.00 & 0.25 & 0.00 & 0.00 & 0.00 & 0.00 & 0.00 \\
\hline \multirow{2}{*}{ Real Interest Rate } & 0.36 & 0.20 & -0.13 & -0.44 & -0.33 & -0.18 & 0.02 & -0.14 \\
\hline & 0.00 & 0.06 & 0.13 & 0.00 & 0.00 & 0.05 & 0.82 & 0.12 \\
\hline
\end{tabular}

Bold values indicate significance. 
Table 3. Correlation Matrix contd.

\begin{tabular}{|c|c|c|c|c|c|c|c|c|c|}
\hline & $\begin{array}{l}\text { Share of } \\
\text { Industry }\end{array}$ & $\begin{array}{c}\text { Domestic } \\
\text { Investment }\end{array}$ & $\begin{array}{c}\text { Share of } \\
\text { Private Sector }\end{array}$ & $\begin{array}{l}\text { Population } \\
<=14\end{array}$ & $\begin{array}{l}\text { Population } \\
>=65\end{array}$ & CPI & $\begin{array}{l}\text { Average } \\
\text { Wage }\end{array}$ & $\begin{array}{l}\text { Share of } \\
\text { Services }\end{array}$ & $\begin{array}{c}\text { Exchange } \\
\text { Rate }\end{array}$ \\
\hline Domestic Investment & $\begin{array}{l}0.29 \\
0.00\end{array}$ & & & & & & & & \\
\hline $\begin{array}{l}\text { Share of Private } \\
\text { Sector }\end{array}$ & $\begin{array}{c}-0.37 \\
0.00\end{array}$ & $\begin{array}{l}0.02 \\
0.72\end{array}$ & & & & & & & \\
\hline $\begin{array}{l}\text { Population } \\
<=14\end{array}$ & $\begin{array}{c}-0.07 \\
0.25\end{array}$ & $\begin{array}{c}-0.17 \\
0.01\end{array}$ & $\begin{array}{c}-0.38 \\
0.00\end{array}$ & & & & & & \\
\hline $\begin{array}{l}\text { Population } \\
>=65\end{array}$ & $\begin{array}{l}0.05 \\
0.40\end{array}$ & $\begin{array}{l}0.17 \\
0.01\end{array}$ & $\begin{array}{l}0.30 \\
0.00\end{array}$ & $\begin{array}{c}-0.95 \\
0.00\end{array}$ & & & & & \\
\hline CPI & $\begin{array}{c}-0.32 \\
0.00\end{array}$ & $\begin{array}{l}0.08 \\
0.26\end{array}$ & $\begin{array}{l}0.74 \\
0.00\end{array}$ & $\begin{array}{l}-0.21 \\
0.003\end{array}$ & $\begin{array}{l}0.13 \\
0.06\end{array}$ & & & & \\
\hline Average Wage & $\begin{array}{c}0.22 \\
0.004\end{array}$ & $\begin{array}{l}0.11 \\
0.14\end{array}$ & $\begin{array}{l}0.21 \\
0.01\end{array}$ & $\begin{array}{c}-0.42 \\
0.00\end{array}$ & $\begin{array}{l}0.32 \\
0.00\end{array}$ & $\begin{array}{l}0.06 \\
0.46\end{array}$ & & & \\
\hline Share of Services & $\begin{array}{l}0.002 \\
0.97\end{array}$ & $\begin{array}{l}0.10 \\
0.13\end{array}$ & $\begin{array}{l}0.60 \\
0.00\end{array}$ & $\begin{array}{c}-0.63 \\
0.00\end{array}$ & $\begin{array}{l}0.56 \\
0.00\end{array}$ & $\begin{array}{l}0.42 \\
0.00\end{array}$ & $\begin{array}{c}0.22 \\
0.004\end{array}$ & & \\
\hline Exchange Rate & $\begin{array}{c}0.21 \\
0.004\end{array}$ & $\begin{array}{l}0.05 \\
0.48\end{array}$ & $\begin{array}{c}-0.10 \\
0.20\end{array}$ & $\begin{array}{l}0.14 \\
0.05\end{array}$ & $\begin{array}{c}-0.30 \\
0.00\end{array}$ & $\begin{array}{l}0.11 \\
0.12\end{array}$ & $\begin{array}{l}0.76 \\
0.00\end{array}$ & $\begin{array}{l}-0.28 \\
0.00\end{array}$ & \\
\hline Freedom & $\begin{array}{c}-0.01 \\
0.88\end{array}$ & $\begin{array}{c}-0.17 \\
0.01\end{array}$ & $\begin{array}{c}-0.45 \\
0.00\end{array}$ & $\begin{array}{l}0.61 \\
0.00\end{array}$ & $\begin{array}{c}-0.57 \\
0.00\end{array}$ & $\begin{array}{c}-0.25 \\
0.00\end{array}$ & $\begin{array}{c}-0.13 \\
0.08\end{array}$ & $\begin{array}{c}-0.63 \\
0.00\end{array}$ & $\begin{array}{l}0.20 \\
0.01\end{array}$ \\
\hline Trade & $\begin{array}{c}-0.23 \\
0.00\end{array}$ & $\begin{array}{l}0.05 \\
0.44\end{array}$ & $\begin{array}{c}-0.12 \\
0.17\end{array}$ & $\begin{array}{l}0.11 \\
0.10\end{array}$ & $\begin{array}{l}0.14 \\
0.03\end{array}$ & $\begin{array}{l}0.09 \\
0.22\end{array}$ & $\begin{array}{c}-0.04 \\
0.59\end{array}$ & $\begin{array}{l}0.20 \\
0.00\end{array}$ & $\begin{array}{l}0.03 \\
0.65\end{array}$ \\
\hline $\begin{array}{l}\text { Secondary School } \\
\text { Enrollment }\end{array}$ & $\begin{array}{l}-0.03 \\
0.83\end{array}$ & $\begin{array}{l}-0.26 \\
0.02\end{array}$ & $\begin{array}{c}-0.30 \\
0.01\end{array}$ & $\begin{array}{l}0.66 \\
0.00\end{array}$ & $\begin{array}{c}-0.59 \\
0.00\end{array}$ & $\begin{array}{c}-0.01 \\
0.97\end{array}$ & $\begin{array}{c}-0.26 \\
0.03\end{array}$ & $\begin{array}{l}-0.57 \\
0.00\end{array}$ & $\begin{array}{l}0.14 \\
0.23\end{array}$ \\
\hline $\begin{array}{l}\text { Labor Force } \\
\text { Secondary School }\end{array}$ & $\begin{array}{l}0.50 \\
0.00\end{array}$ & $\begin{array}{l}0.19 \\
0.08\end{array}$ & $\begin{array}{r}-0.05 \\
0.67\end{array}$ & $\begin{array}{c}-0.28 \\
0.01\end{array}$ & $\begin{array}{l}0.13 \\
0.26\end{array}$ & $\begin{array}{c}-0.01 \\
0.89\end{array}$ & $\begin{array}{l}0.14 \\
0.25\end{array}$ & $\begin{array}{c}-0.01 \\
0.96\end{array}$ & $\begin{array}{l}0.08 \\
0.52\end{array}$ \\
\hline Productivity & $\begin{array}{l}0.37 \\
0.00\end{array}$ & $\begin{array}{l}0.30 \\
0.00\end{array}$ & $\begin{array}{l}0.23 \\
0.00\end{array}$ & $\begin{array}{c}-0.68 \\
0.00\end{array}$ & $\begin{array}{l}0.59 \\
0.00\end{array}$ & $\begin{array}{l}0.08 \\
0.27\end{array}$ & $\begin{array}{l}0.41 \\
0.00\end{array}$ & $\begin{array}{l}0.56 \\
0.00\end{array}$ & $\begin{array}{c}-0.03 \\
0.68\end{array}$ \\
\hline Real Interest Rate & $\begin{array}{c}-0.12 \\
0.17\end{array}$ & $\begin{array}{c}-0.16 \\
0.07\end{array}$ & $\begin{array}{c}-0.29 \\
0.00\end{array}$ & $\begin{array}{l}0.38 \\
0.00\end{array}$ & $\begin{array}{c}-0.37 \\
0.00\end{array}$ & $\begin{array}{l}0.07 \\
0.45\end{array}$ & $\begin{array}{c}-0.11 \\
0.24\end{array}$ & $\begin{array}{c}-0.41 \\
0.00\end{array}$ & $\begin{array}{l}0.02 \\
0.82\end{array}$ \\
\hline
\end{tabular}

Bold values indicate significance. 
Table 3. Correlation Matrix Contd.

\begin{tabular}{lccccc}
\hline & Freedom & Trade & $\begin{array}{c}\text { Secondary } \\
\text { School } \\
\text { Enrollment }\end{array}$ & $\begin{array}{c}\text { Labor Force } \\
\text { Secondary } \\
\text { School }\end{array}$ & Productivity \\
\hline Trade & -0.19 & & -0.22 & 0.08 & 0.10 \\
Secondary School & 0.00 & & 0.06 & 0.50 & 0.11 \\
Enrollment & 0.62 & -0.22 & & & \\
Labor Force & -0.38 & 0.06 & & & \\
Secondary School & 0.00 & 0.08 & -0.41 & & \\
Productivity & -0.73 & 0.10 & -0.57 & 0.55 & \\
& 0.00 & 0.11 & 0.00 & 0.00 & \\
Real Interest Rate & 0.45 & -0.24 & 0.33 & -0.14 & -0.43 \\
& 0.00 & 0.01 & 0.01 & 0.30 & 0.00 \\
\hline
\end{tabular}

Bold values indicate significance.

will result in reducing income inequality by 0.01 percent, keeping everything else constant. This is both statistically and economically insignificant. The signs on the other coefficients in the fixed effects specification in Table 4 generally match their prior expectations as reported in Table 1. However, only three estimates are significant-GDP, Proportion of Population below fourteen, and the Transition Index. Per-capita GDP and income inequality have an inverted-U shaped relationship as predicted by the Kuznets curve. Ceteris paribus, a one percent increase in GDP increases income inequality by 2.91 percent but at a decreasing rate, given that the average GDP per capita is 3.42 . Income inequality will increase by 1.14 percent if proportion of population below the age of fourteen increases by one percent, ceteris paribus. Opening up the economy and transforming institutions has led to increased inequality. If the EBRD Transition index goes up by one percent, income inequality will increase by 0.2 percent, ceteris paribus.

I tried various other specifications. Kyrgyzstan does not have any unemployment data, so I estimated the equation dropping the unemployment variable and results do not change. I tried using lagged FDI instead of current FDI and that also does not change results. In one specification, FDI was interacted with the trend variable. It ends up dropping the FDI variable and keeping the interaction term in a fixed effects specification. Dividing up the sample in different periods also does not yield any results. The squared term of FDI was included in the fixed effects regression but that also resulted in one of the FDI variables being dropped out. Including an interaction term between FDI and share of the private sector also did 
Table 4. Dependent Variable: Gini from Personal Income, 1990-2002

\begin{tabular}{|c|c|c|c|}
\hline Variable & OLS & Fixed Effects & $\begin{array}{l}\text { Instrumental Variable } \\
\text { Fixed Effects }\end{array}$ \\
\hline FDI & $\begin{array}{l}-0.05 * * * \\
(-2.88)\end{array}$ & $\begin{array}{c}-0.01 \\
(-0.40)\end{array}$ & $\begin{array}{c}-0.02 \\
(-0.66)\end{array}$ \\
\hline GDP & $\begin{array}{c}-0.42 \\
(-0.82)\end{array}$ & $\begin{array}{l}3.23 * * \\
(2.05)\end{array}$ & $\begin{array}{l}4.20 * \\
(1.92)\end{array}$ \\
\hline GDP square & $\begin{array}{l}0.01 \\
0.28\end{array}$ & $\begin{array}{l}-0.16^{*} \\
(1.79)\end{array}$ & $\begin{array}{l}-0.21^{*} \\
(-1.69)\end{array}$ \\
\hline Domestic Investment & $\begin{array}{c}-0.05 \\
(-0.89)\end{array}$ & $\begin{array}{c}0.02 \\
(0.45)\end{array}$ & $\begin{array}{c}0.01 \\
(0.17)\end{array}$ \\
\hline Unemployment & $\begin{array}{c}0.03 \\
(1.31)\end{array}$ & $\begin{array}{c}0.03 \\
(1.09)\end{array}$ & $\begin{array}{c}0.02 \\
(0.73)\end{array}$ \\
\hline Inflation & $\begin{array}{l}0.02 * \\
(1.75)\end{array}$ & $\begin{array}{c}0.01 \\
(1.18)\end{array}$ & $\begin{array}{c}0.01 \\
(1.45)\end{array}$ \\
\hline Government Expenditure & $\begin{array}{c}0.12 * * * \\
(3.32)\end{array}$ & $\begin{array}{l}-0.01 \\
(-0.21)\end{array}$ & $\begin{array}{c}-0.03 \\
(-0.64)\end{array}$ \\
\hline $\begin{array}{l}\text { Proportion of Population } \\
<=14\end{array}$ & $\begin{array}{l}0.84 * * * \\
(2.84)\end{array}$ & $\begin{array}{c}1.25^{* * * *} \\
(3.68)\end{array}$ & $\begin{array}{c}1.24 * * * \\
(3.57)\end{array}$ \\
\hline $\begin{array}{l}\text { Proportion of Population } \\
>=65\end{array}$ & $\begin{array}{l}0.57 * * * \\
(2.95)\end{array}$ & $\begin{array}{c}0.19 \\
(0.93)\end{array}$ & $\begin{array}{c}0.13 \\
(0.60)\end{array}$ \\
\hline Share of Private Sector & $\begin{array}{c}0.31 * * * \\
(4.81)\end{array}$ & $\begin{array}{c}0.08 \\
(1.37)\end{array}$ & $\begin{array}{c}0.03 \\
(0.40)\end{array}$ \\
\hline Share of Industrial Sector & $\begin{array}{c}-0.13 \\
(-1.33)\end{array}$ & $\begin{array}{c}-0.10 \\
(-0.95)\end{array}$ & $\begin{array}{c}-0.15 \\
(-1.28)\end{array}$ \\
\hline EBRD Transition Index & $\begin{array}{c}-0.14 \\
(-0.98)\end{array}$ & $\begin{array}{c}0.22 * * \\
(2.04)\end{array}$ & $\begin{array}{c}0.27 * * \\
(2.52)\end{array}$ \\
\hline Political Freedom & $\begin{array}{c}-0.11 * \\
(1.93)\end{array}$ & $\begin{array}{c}-0.05 \\
(-1.06)\end{array}$ & $\begin{array}{c}-0.04 \\
(-0.97)\end{array}$ \\
\hline Trend & $\begin{array}{c}0.03 * * * \\
(4.08)\end{array}$ & $\begin{array}{c}0.02 \\
(1.26)\end{array}$ & $\begin{array}{c}0.02 \\
(1.32)\end{array}$ \\
\hline Constant & $\begin{array}{c}-57.96^{* * *} \\
(-3.81)\end{array}$ & $\begin{array}{c}-48.06^{*} \\
(-1.76)\end{array}$ & $\begin{array}{c}-60.03^{*} \\
(-1.60)\end{array}$ \\
\hline No. of observations & 127 & 127 & 124 \\
\hline No. of groups & 18 & 18 & 18 \\
\hline R-squared & & $\begin{array}{c}\text { Within }(0.44) \\
\text { Between }(0.31) \\
\text { Overall }(0.11)\end{array}$ & $\begin{array}{c}\text { Within }(0.44) \\
\text { Between }(0.34 \\
\text { Overall }(0.14)\end{array}$ \\
\hline Log Likelihood & 105.46 & & \\
\hline
\end{tabular}

The values in the brackets are t-values. $* * *, * *, *$ indicate significant at $1 \%, 5 \%$ and $10 \%$ level of significance. 
not yield any results.

\section{Discussion and Further Results}

Although there is no evidence in the data to support the impact of FDI on income inequality, FDI may affect the different components of income (wage and capital) differently. The theoretical model claims that FDI is reducing income inequality by increasing wages or the return to labor. Also, although full employment is assumed in the theoretical model, in reality, unemployment is high in the Transition countries. Inflows of FDI then should reduce unemployment. Therefore, I examine the impact of FDI on wage inequality, average wages and unemployment separately.

\section{Wage Inequality}

First, I analyze the relationship between FDI and wage inequality. The Gini coefficient calculated from earnings data is used as a wage inequality measure from the WIID database. FDI is predicted to have a positive impact on wage inequality, ceteris paribus. This prediction is based on Feenstra and Hanson (1997) who show both theoretically and empirically that outflow of capital from developed to developing countries increases wage inequality in both countries.

The three control variables typically used in the wage inequality literature are openness to trade (measured as the sum of exports and imports to GDP), level of development (GDP per capita) and levels of education (measured as the total number of secondary students enrolled as a percentage of total population or as the percentage of labor force with secondary education).

The Hecksher-Ohlin Theorem predicts that trade will increase the return to unskilled labor in a relatively unskilled labor abundant country, thereby decreasing the wage inequality and vice-versa in a skilled labor abundant country. Since the transition countries are relatively unskilled labor abundant (versus Western Europe who are their major trade partners), one would expect trade to reduce wage inequality. Figini and Görg (2006) argue that since wage inequality depends on the economic structure of the country, which in turn is connected to the level of development, it is important to control for per capita GDP. The authors also argue that increase in secondary education indicates an increase in supply of skilled labor which would decrease wage inequality, ceteris paribus. An alternate interpretation would be that higher is the percentage of 
labor with secondary education, higher is the likelihood that they are employed and therefore the wage inequality is lower. The results from both the measures of skilled labor are reported in this paper.

The rest of the control variables remain the same as in the income inequality empirical model and have the same expected signs. Equation (2) shows the empirical model for wage inequality with the expected signs written below the variables. $^{30}$

Wage Inequality $_{i t}=$

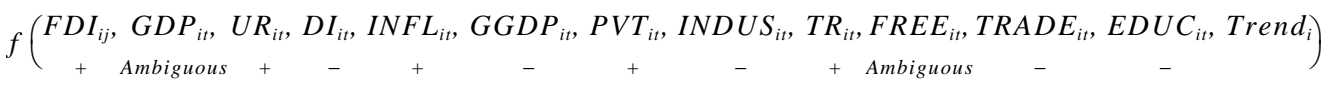

where, FDI=Foreign Direct Investment

GDP=Gross Domestic Product per capita

UR=Unemployment Rate

$\mathrm{DI}=$ Domestic Investment as a proportion of GDP

INFL=Inflation Rate

GGDP=Government Expenditure as a proportion of GDP

PVT=Private Sector Employment in the Economy

INDUS=Industrial Sector Employment in the Economy

TR=EBRD Transition Index

FREE $=$ Political Freedom

TRADE=Openness

EDUC $=$ Education

$\mathrm{i}=$ country, $\mathrm{t}=$ time.

Fixed effects and instrumental variable fixed effects are used. All variables are in $\log$ form. Instrumental variable method is used to control for possible endogeneity problems as a high proportion of people earning lower wages is a determinant of FDI inward stock.

Table 5 shows the empirical results. Overall, the results show that FDI has a positive and significant impact on wage inequality in the fixed effects model. A one percent increase in FDI

will increase wage inequality by 0.14 per cent, ceteris paribus. ${ }^{31}$ The other

\footnotetext{
${ }^{30}$ Figini and Gorg (2006) show theoretically and empirically that FDI and wage inequality have a nonlinear relationship which, however is not supported by evidence from the transition countries.
} 
Table 5. Dependent Variable: Wage Inequality, 1990-2002

\begin{tabular}{|c|c|c|c|c|}
\hline \multirow{2}{*}{$\begin{array}{l}\quad \text { Variable } \\
\text { FDI }\end{array}$} & \multicolumn{2}{|c|}{ Fixed Effects } & \multicolumn{2}{|c|}{ Instrumental Variable Fixed Effects } \\
\hline & $\begin{array}{l}0.14 * \\
(1.92)\end{array}$ & $\begin{array}{l}0.11 * * \\
(2.31)\end{array}$ & $\begin{array}{c}0.65 \\
(0.36)\end{array}$ & $\begin{array}{c}0.17 * * \\
(2.38)\end{array}$ \\
\hline GDP & $\begin{array}{c}0.56 \\
(1.21)\end{array}$ & $\begin{array}{c}-0.38 \\
(-1.55)\end{array}$ & $\begin{array}{c}2.51 \\
(0.36)\end{array}$ & $\begin{array}{l}-0.44 \\
(-1.56)\end{array}$ \\
\hline $\begin{array}{l}\text { Domestic } \\
\text { Investment }\end{array}$ & $\begin{array}{c}-0.13 \\
(-1.44)\end{array}$ & $\begin{array}{c}-0.06 \\
(-0.70)\end{array}$ & $\begin{array}{c}0.01 \\
(0.17)\end{array}$ & $\begin{array}{c}0.01 \\
(0.06)\end{array}$ \\
\hline Unemployment & $\begin{array}{l}0.19 * \\
(1.79)\end{array}$ & $\begin{array}{l}-0.11 * * \\
(-2.05)\end{array}$ & $\begin{array}{c}0.60 \\
(0.40)\end{array}$ & $\begin{array}{l}-0.12^{*} \\
(-1.91)\end{array}$ \\
\hline Inflation & $\begin{array}{c}0.02 \\
(1.04)\end{array}$ & $\begin{array}{c}-0.01 \\
(-0.54)\end{array}$ & $\begin{array}{c}0.01 \\
(0.24)\end{array}$ & $\begin{array}{l}-0.004 \\
(-0.20)\end{array}$ \\
\hline $\begin{array}{l}\text { Government } \\
\text { Expenditure }\end{array}$ & $\begin{array}{l}0.19 * \\
(1.71)\end{array}$ & $\begin{array}{c}0.12 \\
(0.42)\end{array}$ & $\begin{array}{c}0.55 \\
(0.42)\end{array}$ & $\begin{array}{c}0.10 \\
(0.92)\end{array}$ \\
\hline $\begin{array}{l}\text { Share of Private } \\
\text { Sector }\end{array}$ & $\begin{array}{c}0.10 \\
(0.48)\end{array}$ & $\begin{array}{c}-0.04 \\
(-0.31)\end{array}$ & $\begin{array}{c}0.28 \\
(0.35)\end{array}$ & $\begin{array}{c}-0.03 \\
(-0.15)\end{array}$ \\
\hline $\begin{array}{l}\text { Share of } \\
\text { Industrial Sector }\end{array}$ & $\begin{array}{l}-0.25 \\
(-1.10)\end{array}$ & $\begin{array}{c}0.06 \\
(0.37)\end{array}$ & $\begin{array}{c}-0.64 \\
(-0.43)\end{array}$ & $\begin{array}{c}0.05 \\
(0.29)\end{array}$ \\
\hline $\begin{array}{l}\text { EBRD } \\
\text { Transition Index }\end{array}$ & $\begin{array}{c}-0.81 \\
(-1.51)\end{array}$ & $\begin{array}{c}0.52 \\
(1.57)\end{array}$ & $\begin{array}{c}-2.69 \\
(-0.40)\end{array}$ & $\begin{array}{c}0.22 \\
(0.49)\end{array}$ \\
\hline $\begin{array}{l}\text { Political } \\
\text { Freedom }\end{array}$ & $\begin{array}{c}0.06 \\
(0.67)\end{array}$ & $\begin{array}{c}-0.01 \\
(-0.09)\end{array}$ & $\begin{array}{c}-0.14 \\
(-0.19)\end{array}$ & $\begin{array}{c}0.07 \\
(0.48)\end{array}$ \\
\hline Trade & $\begin{array}{c}0.22 \\
(1.14)\end{array}$ & $\begin{array}{c}-0.01 \\
(-0.08)\end{array}$ & $\begin{array}{c}0.06 \\
(0.10)\end{array}$ & $\begin{array}{c}-0.02 \\
(-0.16)\end{array}$ \\
\hline EDUC & $\begin{array}{c}0.15 \\
(0.35)\end{array}$ & & $\begin{array}{c}0.32 \\
(0.31)\end{array}$ & \\
\hline $\begin{array}{l}\text { Percentage of } \\
\text { Labor Force with } \\
\text { a Secondary } \\
\text { Education }\end{array}$ & & $\begin{array}{c}0.06 \\
(0.57)\end{array}$ & & $\begin{array}{c}-0.04 \\
(-0.36)\end{array}$ \\
\hline Trend & $\begin{array}{l}-0.03 \\
(0.89)\end{array}$ & $\begin{array}{c}-0.01 \\
(-0.38)\end{array}$ & $\begin{array}{c}-0.15 \\
(-0.34)\end{array}$ & $\begin{array}{c}-0.01 \\
(-0.36)\end{array}$ \\
\hline Constant & $\begin{array}{l}55.84 \\
(0.90)\end{array}$ & $\begin{array}{l}17.11 \\
(0.62)\end{array}$ & $\begin{array}{c}287.20 \\
(0.34)\end{array}$ & $\begin{array}{l}18.13 \\
(0.62)\end{array}$ \\
\hline No. of observations & 42 & 54 & 42 & 52 \\
\hline No. of groups & 13 & 10 & 13 & 10 \\
\hline R-squared & $\begin{array}{l}\text { Within }(0.53) \\
\text { Between }(0.41) \\
\text { Overall }(0.41)\end{array}$ & $\begin{array}{l}\text { Within }(0.79) \\
\text { Between }(0.08) \\
\text { Overall }(0.02)\end{array}$ & $\begin{array}{c}\text { Within (N.A.) } \\
\text { Between (0.38) } \\
\text { Overall (0.41) }\end{array}$ & $\begin{array}{l}\text { Within }(0.76) \\
\text { Between }(0.02) \\
\text { Overall }(0.01)\end{array}$ \\
\hline
\end{tabular}

The values in the brackets are t-values. $* * *, * *, *$ indicate significant at $1 \%, 5 \%$ and $10 \%$ level of significance. 
control variables are statistically insignificant except unemployment, which changes signs across specifications. Average Wages

Average Wages $_{i t}=$

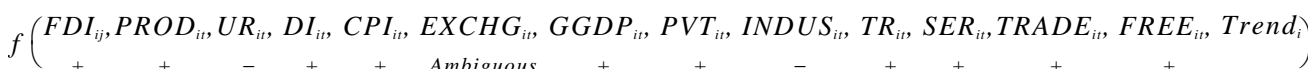

where, FDI=Foreign Direct Investment

PROD=Productivity as measured by GDP/Labor Force

UR=Unemployment Rate

$\mathrm{DI}=$ Domestic Investment as a proportion of GDP

$\mathrm{CPI}=$ Consumer Price Index

EXCHG=Exchange Rate

GGDP=Government Expenditure as a proportion of GDP

PVT=Private Sector Employment in the Economy

INDUS=Industrial Sector Employment in the Economy

TR=EBRD Transition Index

TRADE=Openness

SER=Service Sector Employment in the Economy

$\mathrm{i}=$ country, $\mathrm{t}=$ time.

Next, the effect of inward FDI on average wages in the economy is analyzed. The empirical model is shown in equation (3). Average wages are calculated across all the sectors in the economy and used as a dependent variable. ${ }^{32}$ The main explanatory variable is FDI and is hypothesized to have a positive effect on wages based on the economic theory laid out in Section II. Since wages are measured nominally in local currency, the wage equation includes the Consumer Price Index and the exchange rate as control variables. Following Onaran and Stockhammer (2006), productivity and trade are also included as control variables and both are expected to have a positive impact on wages. The rest of

\footnotetext{
${ }^{31}$ Using the secondary education enrollment measure, FDI does not have a significant impact on income inequality in the fixed effects instrumental variable specification. This difference in result arises probably due to the lagged effect of secondary education versus the immediate impact of number of labor with secondary education. This is a potential avenue for future research. Another reason simply may be due to difference in sample size as dropping the secondary school enrollment variable increases the number of included observations to 121 .

${ }^{32}$ To be consistent, I have only included wages from ISIC-Rev.3.
} 
the control variables include EBRD Liberalization Index, share of the private sector, share of industrial sector, share of services sector, government expenditure, domestic investment, unemployment rate, political freedom and trend. It is hypothesized that the Liberalization, political freedom, increase in share of private sector, increase in share of services sector and more domestic investment would increase wages. Share of industrial sector and unemployment will decrease wages. ${ }^{33}$

Both fixed effects and instrumental fixed effects are used to estimate the regression equation. All variables are again in log form. Tables 6 report the results. Average wages are significantly increasing in FDI in both the specifications. A one percent increase in FDI increases average wages by 0.20 percent, everything else being held constant. This is consistent with the economic theory that says FDI increases the returns to the labor force and previous empirical literature including Onaran and Stockhammer (2006). The authors find that FDI in Central and East European countries has a positive and significant impact on wages only in the capital and skill-intensive sectors in the post-transition era of the CEECs. The signs on the rest of the variables are consistent with prior expectations except trade and share of the industrial sector. Trade is reducing average wages, ceteris paribus and industrial sector employment is increasing average wages in the country.

\section{Unemployment}

Finally, the impact of FDI on unemployment is analyzed. FDI is again the main explanatory variable. Following the literature, Baccaro and Rei (2005), inflation rate, real interest rate, productivity and trade are used as control variables. Inflation rate and Unemployment rate have an inverse relationship at least in the short run as per Phillips curve. Increase in real interest rate will lead to increase in unemployment, ceteris paribus, as firms lower investment and therefore do not hire workers. Baccaro and Rei (2005) argue that productivity has a lagged negative impact-if workers do not change their wage demands with increases in productivity, unemployment will fall. Increase in trade may decrease unemployment in transition countries because the empirical results from Table 6 show that trade is decreasing average wages. The rest

\footnotetext{
${ }^{33}$ An empirical specification (for average wages) including control for skilled labor was estimated. FDI has a statistically insignificant impact on average wages, when secondary school enrollment is used but has a positive and significant impact (on average wages) when the percentage of labor force which have secondary school education is used.
} 
Table 6. Dependent Variable: Average Wages, 1990-2002

\begin{tabular}{|c|c|c|}
\hline Variable & Fixed Effects & Instrumental Variable Fixed Effects \\
\hline FDI & $\begin{array}{l}0.11 * \\
(3.84)\end{array}$ & $\begin{array}{l}0.20^{*} \\
(4.41)\end{array}$ \\
\hline Productivity & $\begin{array}{l}0.99 * \\
(8.79)\end{array}$ & $\begin{array}{l}1.05^{*} \\
(8.77)\end{array}$ \\
\hline Domestic Investment & $\begin{array}{c}-0.06 \\
(-1.43)\end{array}$ & $\begin{array}{c}-0.08 \\
(-0.58)\end{array}$ \\
\hline Unemployment & $\begin{array}{c}-0.02 \\
(-0.84)\end{array}$ & $\begin{array}{c}-0.10 \\
(-0.37)\end{array}$ \\
\hline Consumer Price Index & $\begin{array}{c}0.84 * \\
(16.66)\end{array}$ & $\begin{array}{c}0.89 * \\
(16.29)\end{array}$ \\
\hline Exchange Rate & $\begin{array}{l}0.13^{*} \\
(2.70)\end{array}$ & $\begin{array}{c}0.07 \\
(1.20)\end{array}$ \\
\hline Government Expenditure & $\begin{array}{l}0.20 * \\
(3.62)\end{array}$ & $\begin{array}{l}0.25^{*} \\
(4.19)\end{array}$ \\
\hline Share of Private Sector & $\begin{array}{l}0.18^{*} \\
(2.57)\end{array}$ & $\begin{array}{c}0.17 * * \\
(2.23)\end{array}$ \\
\hline Share of Industrial Sector & $\begin{array}{l}0.32 * \\
(2.79)\end{array}$ & $\begin{array}{l}0.31 * \\
(2.58)\end{array}$ \\
\hline Share of Services Sector & $\begin{array}{l}0.44 * \\
(3.09)\end{array}$ & $\begin{array}{c}0.25 \\
(1.57)\end{array}$ \\
\hline EBRD Transition Index & $\begin{array}{c}-0.19 \\
(-1.27)\end{array}$ & $\begin{array}{c}-0.07 \\
(-0.44)\end{array}$ \\
\hline Political Freedom & $\begin{array}{l}0.20 * \\
(3.57)\end{array}$ & $\begin{array}{l}0.22 * \\
(3.52)\end{array}$ \\
\hline Trade & $\begin{array}{l}-0.30 * \\
(-4.45)\end{array}$ & $\begin{array}{l}-0.31^{*} \\
(-4.37)\end{array}$ \\
\hline Trend & $\begin{array}{l}-0.002 \\
(0.17)\end{array}$ & $\begin{array}{c}-0.02 * * * \\
(-1.79)\end{array}$ \\
\hline Constant & $\begin{array}{c}-8.71 \\
(-0.50)\end{array}$ & $\begin{array}{l}26.39 \\
(1.28)\end{array}$ \\
\hline No. of observations & 147 & 144 \\
\hline No. of groups & 18 & 18 \\
\hline R-squared & $\begin{array}{l}\text { Within }(0.99) \\
\text { Between }(0.12) \\
\text { Overall }(0.19)\end{array}$ & $\begin{array}{c}\text { Within }(0.99) \\
\text { Between }(0.03) \\
\text { Overall }(0.09)\end{array}$ \\
\hline
\end{tabular}

The values in the brackets are t-values. $* * *, * *, *$ indicate significant at $1 \%, 5 \%$ and $10 \%$ level of significance.

of the control variables are the same as in average wages. It is hypothesized that the Liberalization, political freedom will increase unemployment as the economy transforms and the firms become more efficient. The firms are not under any pressure 
to hire people. Intuitively, increases in service sector, industrial sector, private sector employment and domestic investment and government expenditures will decrease unemployment. ${ }^{34}$ The regression equation is shown in equation (4).

Table 7. Dependent Variable: Unemployment Rate, 1990-2002

\begin{tabular}{|c|c|c|}
\hline Variable & Fixed Effects & Instrumental Variable Fixed Effects \\
\hline FDI & $\begin{array}{c}0.05 \\
(0.70)\end{array}$ & $\begin{array}{c}0.05 \\
(0.66)\end{array}$ \\
\hline Productivity & $\begin{array}{l}-1.87 * \\
(-4.73)\end{array}$ & $\begin{array}{l}-1.84 * \\
(-4.51)\end{array}$ \\
\hline Real Interest Rate & $\begin{array}{c}0.01 \\
(0.44)\end{array}$ & $\begin{array}{c}0.01 \\
(0.37)\end{array}$ \\
\hline Domestic Investment & $\begin{array}{c}-0.15 \\
(-0.81)\end{array}$ & $\begin{array}{c}-0.16 \\
(-0.85)\end{array}$ \\
\hline Inflation Rate & $\begin{array}{c}-0.01 \\
(-0.33)\end{array}$ & $\begin{array}{c}-0.01 \\
(-0.32)\end{array}$ \\
\hline Government Expenditure & $\begin{array}{c}-0.30 \\
(-1.46)\end{array}$ & $\begin{array}{c}-0.30 \\
(-1.46)\end{array}$ \\
\hline Share of Private Sector & $\begin{array}{c}0.11 \\
(0.35)\end{array}$ & $\begin{array}{c}0.10 \\
(0.30)\end{array}$ \\
\hline Share of Industrial Sector & $\begin{array}{c}0.49 \\
(1.04)\end{array}$ & $\begin{array}{c}0.48 \\
(1.00)\end{array}$ \\
\hline Share of Services Sector & $\begin{array}{l}1.71 * * \\
(2.42)\end{array}$ & $\begin{array}{l}1.72 * * \\
(2.38)\end{array}$ \\
\hline EBRD Transition Index & $\begin{array}{c}-0.71 \\
(-0.97)\end{array}$ & $\begin{array}{c}-0.68 \\
(-0.90)\end{array}$ \\
\hline Political Freedom & $\begin{array}{l}-0.75^{*} \\
(-3.76)\end{array}$ & $\begin{array}{l}-0.76^{*} \\
(-3.75)\end{array}$ \\
\hline Trade & $\begin{array}{c}-0.38 * * * \\
(-1.73)\end{array}$ & $\begin{array}{c}-0.38 * * * \\
(-1.67)\end{array}$ \\
\hline Trend & $\begin{array}{c}0.06^{* * * *} \\
(1.89)\end{array}$ & $\begin{array}{c}0.06 * * * \\
(1.71)\end{array}$ \\
\hline Constant & $\begin{array}{c}-104.20 * * * \\
(-1.64)\end{array}$ & $\begin{array}{l}-97.68 \\
(-1.46)\end{array}$ \\
\hline No. of observations & 113 & 112 \\
\hline No. of groups & 17 & 17 \\
\hline R-squared & $\begin{array}{l}\text { Within }(0.47) \\
\text { Between }(0.09) \\
\text { Overall }(0.04)\end{array}$ & $\begin{array}{c}\text { Within }(0.47) \\
\text { Between }(0.09) \\
\text { Overall }(0.04)\end{array}$ \\
\hline
\end{tabular}

The values in the brackets are t-values. $* * * * * *$, indicate significant at $1 \%, 5 \%$ and $10 \%$ level of significance. 
Both fixed effects and instrumental variable fixed effects are used to estimate the equation. The econometric results are reported in Table 7 and there is no statistical evidence that FDI affects unemployment. The instrumental variables fixed effects support the prior expectations on the signs of the following variables-productivity, trade and government expenditures. Increase in share of the service sector is reducing unemployment. Increase in political freedom is also reducing unemployment.

Unemployment $_{i t}=$

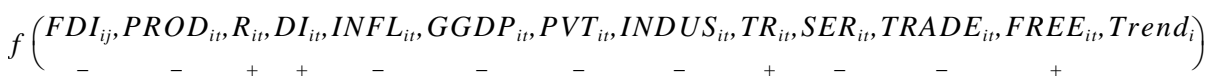

where, FDI=Foreign Direct Investment

PROD=Lagged Productivity as measured by GDP/Labor Force

$\mathrm{R}=$ Real Interest Rate

DI=Domestic Investment as a proportion of GDP

INFL=Inflation Rate

GGDP=Government Expenditure as a proportion of GDP

PVT=Private Sector Employment in the Economy

INDUS=Industrial Sector Employment in the Economy

TR=EBRD Transition Index

$\mathrm{SER}=$ Service Sector Employment in the Economy

TRADE=Openness

FREE=Political Freedom

$\mathrm{i}=$ country, $\mathrm{t}=$ time.

In essence this section shows that inflow of FDI increases wages and wage inequality. The wage inequality is increased between the people who are working. However, these data do not support the hypothesis that unemployment and income inequality are affected by inflow of FDI. ${ }^{35}$

The econometric evidence about the impact of FDI is intriguing. Income inequality comprises wage inequality and capital income inequality. Overall,

\footnotetext{
${ }^{34}$ Francesconi et al. (2000) examine the impact of education on unemployment for the U.S. Following this paper, I also include education as an explanatory variable for unemployment. FDI positively and significantly increases unemployment when education is measured as the percentage of labor force that has secondary education.

${ }^{35}$ One probable reason for this might be that although FDI creates jobs but at the same time because of restructuring, multinational companies might be laying off excess workers. Therefore the net impact on both unemployment and income inequality may be uncertain.
} 
income inequality is not being affected by FDI, but wage inequality increases due to FDI. This would imply that capital income inequality must have decreased in these countries. One explanation for this could be that Eastern Bloc countries had over invested in capital, and the inflow of FDI would have reduced the returns to capital, thereby decreasing income inequality. ${ }^{36}$ Another possible explanation may be the lack of consistent data availability. Further, Cornia (2003) and Milanovic (1998) report that capital income increases only in a limited manner in transition countries because there is under reporting of income in Household Budget Surveys and under sampling of high income groups.

\section{Conclusion}

This paper empirically examines the effect of FDI on income inequality, wages and unemployment for transitional economies. The economies have experienced rising income inequality and FDI inward stocks since 1989 (CEB countries) and 1991 (CIS countries). The results show scant support for any impact of FDI on income inequality or unemployment. However, FDI is increasing average wages, which is interpreted as support for my theoretical model that FDI increases the returns to labor. FDI is also increasing wage inequality, which is consistent with previous literature.

In sum, FDI has no negative impact on development or income inequality at least for transition countries. FDI has a positive impact on the economy by increasing the average wages. The evidence from Bhandari (2006), Borraz and López-Córdova (2007), and this paper show that globalization, especially FDI, is good for development both in developed and developing countries.

This paper offers further avenues of research. One extension would be to investigate further the result that wage inequality is increased by FDI but income inequality is not, especially when wage inequality is a major composition of income inequality. It would also be useful to differentiate between types of FDI, specifically mergers and acquisitions and greenfield investment. Further, the role of manufacturing FDI in the process might also prove to be interesting. Related to the

\footnotetext{
${ }^{36}$ Basically this explanation hinges on the distribution of capital in these countries. Suppose privatization gave everyone an equal share of the previously government owned capital and an inflow of FDI would reduce its return. This would then fit both the theoretical model and the empirics. Nellis (2000) shows that mass and rapid privatization was carried out in the transition countries with no concern for the quality of the owners. Notable exceptions include Hungary, Estonia, East Germany and Poland [Nellis (2000)]. In Russia, however, the mass privatization led to oligarchy [Nellis (2000)].
} 
role of manufacturing FDI, firm level data might be very useful to discern wage and employment effects. Another extension could be to use region level data within countries to test the relationship between FDI and income inequality.

\section{Acknowledgments}

This paper is based on the third chapter of my dissertation. I thank my committee co-chairs, Bruce Blonigen and Stephen Haynes, for their comments. I would also like to thank Ronald Davies, member of my dissertation committee, for his helpful insights. I would also like to express my gratitude towards the seminar participants at the seventy-sixth Southern Economic Association conference, Charleston, 2006 and my anonymous referees for their many comments and suggestions. I would also like to thank my anonymous referees for their comments. Any remaining errors or omissions are the responsibility of the author.

Received 5 February 2007, Accepted 3 July 2007

\section{References}

Aghion, P. and S. Commander (1999) On the Dynamics of Inequality in the Transition, Economics of Transition, 7(2), pp. 275-98.

Axarloglou, K., W. Casey and H. Han (2002) Inward Foreign Direct Investments in the US: An Empirical Analysis of their Impact on State Economies, Paper presented at European International Business Academy, December 8-10, http://www.aueb.gr/ deos/EIBA2002.files/Index.htm

Baccaro, L. and D. Rei (2005) Institutional Determinants of unemployment in OECD Countries: A time series cross-section analysis (1960-1998), International Institute for Labor Studies Discussion Paper No. 16005, International Labor Organization, Geneva, Switzerland, www.ilo.org.

Basu, P. and A. J. Guariglia (2006) Foreign Direct Investment, Inequality and Growth, Journal of Macroeconomics, forthcoming.

Bhagwati, J. (2004) In Defense of Globalization, Oxford University Press.

Bhandari, B. (2006) Does Foreign Direct Investment Affect U.S. Income Inequality?, Working Paper, http://falcon.fsc.edu/bbhandari/.

Birdsall, N. (2005) Why Inequality Matters in a Globalizing World, 2005 WIDER Annual Lecture, October 26, http://www.wider.unu.edu/public-lectures/wider-annual-lecture2005/WIDER-2005-annual-lecture-slides.pdf.

Borraz, F. and E. López-Córdova (2007) Has Globalization Deepened Income Inequality in Mexico?, Global Economy Journal, 7(1), Article 6. 
Campos, N.F. and Y. Kinoshita (2003) Why Does FDI Go Where it Goes? New Evidence from the Transition Economies, IMF Working Paper No. 228, International Monetary Fund, Washington D.C., www.imf.org

Falzoni, A. M., G. S. F. Bruno and R. Crinò, (2004) Foreign Direct Investment, Wage Inequality and Skilled Labor Demand in EU Accession Countries, Working Paper No. 04/188, Centro Studi Luca d'Agliano, Universta' Degli Studi Di Milano, Milan, Italy, http://papers.ssrn.com/sol3/papers.cfm?abstract_id=676652.

Cornia, G. A. (2003) The Impact of Liberalization and Globalization on Within-country Income Inequality, CESifo Economic Studies, 49(4), pp. 581-616, CESIfo, Munich, Germany.

Deaton A. S. and C. H. Paxson (1997) The Effects of Economic and Population Growth on National Savings and Inequality, Demography, 34, pp. 97-114.

DeMelo, M., C. Denizer and A. Gelb (1996) From Plan to Market: Patterns of Transition, World Bank Policy Research Working Paper No. 1564, World Bank, Washington D.C., http://www-wds.worldbank.org/external/default/WDSContentServer/IW3P/IB/ 1996/01/01/000009265_3961019173154/Rendered/PDF/multi0page.pdf.

Dreher, A. and N. Gaston (2006a) Does Globalization Affect Growth? Evidence from New Index of Globalization, Applied Economics, 38(10), pp. 1091-1110.

Dreher, A. and N. Gaston (2006b) Has Globalization Increased Inequality?, Swiss Institute for Business Cycle Research Working Paper 06-140, Swiss Institute for Business Cycle Research (KOF), Swiss Federal Institute of Technology Zurich (ETH), Zurich, Switzerland.

EBRD (2000) EBRD Transition Report: Ten Years of Transition, EBRD Publications Desk.

EBRD (2003) EBRD Transition Report: Integration and Regional Cooperation, EBRD Publications Desk.

Feenstra, R. C. and G. H. Hanson (1997) Foreign Direct Investment and relative wages: Evidence from Mexico's Maquiladoras, Journal of International Economics, 42, pp. 371-393.

Ferreira, F. H. G. (1999) Economic Transition and the Distributions of Income and Wealth, Economics of Transition, 7(2), pp. 377-410.

Ferreira, F. H. G. and J. Litchfield (1998) The Roles of Structural Factors and Macroeconomic Instability in Explaining Brazilian Inequality in the 1980s, LSE Discussion Paper No. DARP 41, STICERD, London School of Economics and Political Science, London, U.K., http://sticerd.lse.ac.uk/dps/darp/darp41.pdf.

Figini, P. and H. Görg (2006) Does Foreign Direct Investment Affect Wage Inequality? An Empirical Investigation, IZA Discussion Paper No. 2336, Institute for the Study of Labor, Bonn, Germany.

Figlio, D. N. and B. Blonigen (2000) The Effects of Foreign Direct Investment on Local Communities, Journal of Urban Economics, 48, pp. 338-363.

Francesconi, M, J.M. Orszag, E.S. Phelps and G. Zoega (2000) Education and the natural rate of unemployment, Oxford Economic Papers, 52(1), pp. 204-223. 
Garibaldi, P., N. Mora, R. Sahay and J. Zettelmeyer (2001) What Moves Capital to Transition Economies?, IMF Staff Papers, 48, International Monetary Fund, Washington D.C.

Garner T. I. and K. Terrell (1998) A Gini Decomposition Analysis of Inequality in the Czech and Slovak Republics during the Transition, Economics of Transition, 6(1), pp. 23-46.

Gradstein, M., B. Milanovic, and Y. Ying (2001) Democracy and Income Inequality: An Empirical Analysis, The World Bank Development Research Group Working Paper No. 2561, World Bank, Washington D.C., http://www-World wds.worldbank.org/ external/default/WDSContentServer/IW3P/IB/2001/04/07/000094946_01032905305396 /Rendered/PDF/multiopage.pdf

Gustafsson, B. and M. Johansson (1999) In Search of Smoking Guns: What Makes Income Inequality Vary Over Time in Different Countries?, American Sociological Review, 64, pp. 585-605.

Hanson, G. H. (2005) Globalization, Labor Income, Poverty in Mexico, NBER Working Paper No. 11027, National Bureau of Economic Research, Cambridge, Mass., http:/ /www.nber.org/papers/w11027.

Harrison, A. and G. H. Hanson (1999) Who Gains from Trade Reform? Some Remaining Puzzles, Journal of Development Economics, 59, pp. 125-154.

Holland, D. and N. Pain (1998) The Diffusion of Innovation in Central and Eastern Europe: A Study of the Determinants and Impact of Foreign Direct Investment, NIESR Discussion Papers 98, NIESR, London, U.K., http://www.niesr.ac.uk/pubs/ dps/dp98.pdf.

Hunya, G. and I. Geishecker (2005) Employment Effects of Foreign Direct Investment in Central and Eastern Europe, WIIW Research Reports No. 321, August, Vienna Institute for International Economic Studies, Vienna, Austria, http://wiiw66.wsr.ac.at/ pdf/RR321.

Ivaschenko, O. (2002) Growth and Inequality: Evidence from Transitional Economies, CESIfo Working Paper No. 476, CESIfo, Munich, Germany, http://papers.ssrn.com/ sol3/papers.cfm?abstract_id=322740.

Lambert, P. (2001) The Distribution and Redistribution of Income, Third Edition, Manchester University Press.

Levy, F. and Richard J. M. (1992) U.S. Earnings Levels and Earnings Inequality: A Review of Recent Trends and Proposed Explanations, Journal of Economic Literature, 30(3), pp. 1333-81.

Mah, J. S. (2002) The Impact of Globalization on Income Distribution: the Korean experience, Applied Economic Letters, 9, pp. 1007-1009.

Mahler, V. A., D. K. Jesuit and D. D. Roscoe (1999) Exploring the Impact of Trade and Investment on Income Inequality: A Cross-National Sectoral Analysis of the Developed Countries, Comparative Political Studies, 32 (3), pp. 363-395.

Milanovic, B. (1998) Income, Inequality and Poverty during the Transition from Planned to Market Economy, World Bank Regional and Sectoral Studies No. 17419, World 
Bank., Washington D.C., http://www-wds.worldbank.org/external/default/WDS ContentServer/IW3P/IB/1998/02/01/000009265_3980319100155/Rendered/PDF/ multi_page.pdf

Milanovic, Branko (1999) Explaining the Increase in Inequality during Transition, Economics of Transition, 7(2), pp. 299-343.

Milanovic, B. (2002) Can we discern the Effect of Globalization on Income Distribution?, World Bank Policy Research Working Paper No. 2876, World Bank, Washington D.C., http://www-wds.worldbank.org/external/default/WDSContentServer/IW3P/IB/ 2002/09/24/000094946_0209060421403/Rendered/PDF/multi0page.pdf

Mocan, H.N. (1999) Structural Unemployment, Cyclical Unemployment and Income Inequality, Review of Economics and Statistics, 81(1), pp. 122-134.

Onaran, Ö and E. Stockhammer (2006) The effect of foreign trade and FDI on wages in the Central and Eastern European countries in the post-transition era: A sectoral analysis, Vienna Institute of Economics \& B.A. Department of Economics Working Paper Series No. 94, Vienna Institute of Economics \& B.A., Vienna, Austria, http:/ /www.wu-wien.ac.at/arbeitsmarkt/staff/onaran/

Rodrik, Dani (1997) Has Globalization Gone Too Far?, Institute of International Economics, Washington D.C.

Rodrik, D. (1999) Democracies Pay Higher Wages, Quarterly Journal of Economics, 114 (3), pp. 707-38, August.

Todaro, M. P. and S. C. Smith (2004) Economic Development, $9^{\text {th }}$ Edition, AddisonWesley.

Wu, X., J. M. Perloff and A. Golan (2002) Effects of Government Policies on Income Distribution and Welfare, Working Paper, http://are.berkeley.edu/ perloff/PDF/tax.pdf, February.

Xing, Y. and K. H. Zhang (2004) FDI and Regional Income Disparity in Host Countries: Evidence from China, Economica Internazionale, 57(3), pp. 363-379.

Yemtsov, Ruslan (2001) Inequality and Income Distribution in Georgia, IZA Discussion

Paper No. 252, World Bank, Washington D.C., and IZA, Bonn, Germany, www.iza.org.

Yudaeva, Ksenia (2002) Globalization and Inequality in CIS countries: Role of Institutions, GDN Conference, Cairo, Global Development Network, http://www. gdnet.org/pdf/Fourth_Annual_Conference/Parallels2/CIS/Yudaeva_paper.pdf.

Zhang, X. and K. H. Zhang (2003) How does Globalisation Affect Regional Inequality within a Developing Country? Evidence from China?, Journal of Development Studies, 39(4), pp. 47-67. 


\section{Appendix 1 [Reproduced from Bhandari (2006)]}

\section{Closed Economy}

Min $r K+w L$ s.t. $K_{c}^{\alpha}\left(L_{A}+L_{B}\right)^{1-\alpha}=Q$

Optimal $K^{*}, L^{*}$ satisfy $-M P_{L} / M P_{K}=w / r$

From Cobb-Douglas results, $w / r=(1-\alpha) K / \alpha\left(L_{A}+L_{B}\right)$

$K_{c} /\left(L_{A}+L_{B}\right)=a w(1-a) r=d$

Since endowments are fully utilized,

$K^{*} / L^{*}=\alpha w /(1-\alpha) r=d^{*}$ and $\backslash w / r=\left[(1-\alpha) K^{*}\right] /\left[\alpha L^{*}\right]$

where $K^{*}=K_{c}$ and $L^{*}=L_{A}+L_{B}$

Output produced is $Q^{*}=\left(K^{*}\right)^{\alpha}\left(L^{*}\right)^{1-\alpha}$

$K^{*}=\left(d^{*}\right) Q^{*}$ and $L^{*}=\left(d^{*}\right)^{-\alpha} Q^{*}$

Income of Labor $=w\left(d^{*}\right)^{-\alpha} Q^{*}$

Since $L_{A}=L_{B}, m_{A}=m_{B}=w L_{A}=w L_{B}=w\left(d^{*}\right)^{-\alpha} Q^{*} / 2$

Income of Capital $=m_{C}=r\left(d^{*}\right)^{1-\alpha} Q^{*}$

Total Income, $m=m_{A}+m_{B}+m_{C}=\left[w+r d^{*}\right]\left(d^{*}\right)^{-\alpha} Q^{*}$

Substituting $d$ inside the bracket, we get, $m=\left[w\left(d^{*}\right)^{-\alpha} /(1-\alpha)\right] Q^{*}$

Each person consumes as much of the good as money can buy

$D_{A}(p)=m_{A} / p=w\left(d^{*}\right)^{-\alpha} Q^{*} / 2=m_{B} / p=D_{B}(p)$

$D_{C}(p)=m_{C} l p=r\left(d^{*}\right)^{1-\alpha} Q^{*}$

Total Demand, $D(p)=D_{A}(p)+D_{B}(p)+D_{C}(p)=m / p=T C\left(Q^{*}\right) / p$

Total Revenue, p.D $(p)=T C\left(Q^{*}\right)$. This implies that profits are zero.

Income Distribution

Coefficient of Variation $=C V=\frac{\text { Sample Standard Deviation }}{\text { Sample Mean }}$

Sample Mean of all Incomes $=m / 3=\left[\left(\frac{w}{1-\alpha}\right)^{1-\alpha}\left(\frac{r}{\alpha}\right)^{\alpha}\left(\frac{Q^{*}}{3}\right)\right]$

Sample Standard Deviation $=\sqrt{\sum\left(X_{i}-\bar{X}\right)^{2} / n}$

Sample Standard Deviation $=\left[\left(\frac{w}{1-\alpha}\right)^{1-\alpha}\left(\frac{r}{\alpha}\right)^{\alpha}\left(\frac{Q^{*}(3 \alpha-1)}{3 \sqrt{2}}\right)\right]$

$C V_{\text {Closed }}=\frac{1}{\sqrt{2}}\left\{\frac{\left[\left(\frac{w}{1-\alpha}\right)^{1-\alpha}\left(\frac{r}{\alpha}\right)^{\alpha}\left(Q^{*}(3 \alpha-1)\right)\right]}{\left[\left(\frac{w}{1-\alpha}\right)^{1-\alpha}\left(\frac{r}{\alpha}\right)^{\alpha}\left(Q^{*}\right)\right]}\right\}=(\sqrt{2})(3 \alpha-1) / 2$ 


\section{Open Economy}

The production function is now, $Q=\left(K_{C}+K_{F}\right)^{\alpha}\left(L_{A}+L_{B}\right)^{1-\alpha}$

Min $r K+$ wL s.t. $\left(K_{C}+K_{F}\right)^{\alpha}\left(L_{A}+L_{B}\right)^{1-\alpha}=Q$

From Cobb-Douglas results $w / r=M P_{L} / M P_{K}$

$\left(K_{C}+K_{F}\right) /\left(L_{A}+L_{B}\right)=\alpha w^{o} /(1-\alpha) r^{o}=d^{o}$

Since endowments are fully utilized

$K^{o} / L^{o}=\alpha w^{o} /(1-\alpha) r^{o}=d^{o}$ and $\therefore w^{o} / r^{o}=\left[(1-\alpha) K^{o}\right] /\left[\alpha L^{o}\right]$

where $K^{o}=K_{C}+K_{F}$ and $L^{o}=L_{A}+L_{B}$

Output produced is $Q^{o}=\left(K^{o}\right)^{\alpha}\left(L^{o}\right)^{1-\alpha}$

$K^{o}=\left(d^{o}\right)^{1-\alpha} Q^{o}$ and $L^{o}=\left(d^{o}\right)^{-\alpha} Q^{o}$

Income of Labor $=w^{o}\left(d^{o}\right)^{-\alpha} Q^{o}$

Since $L_{A}=L_{B}, m_{A}^{o}=m_{B}^{o}=w^{o} L_{A}=w^{o} L_{B}=w^{o}\left(d^{o}\right)^{-\alpha} Q^{o} / 2$

Income of Domestic Capital $=m_{C}^{o}=r^{o}\left(d^{o}\right)^{1-\alpha} Q^{o}-r^{o} K_{F}$

Total Domestic Income, $m^{o}=m_{A}^{o}+m_{B}^{o}+m_{C}^{o}=\left[\left(w^{o}\left(d^{o}\right)^{-\alpha} Q^{o}\right) /(1-\alpha)\right]-r^{o} K_{F}$

Each person consumes as much of the good as money can buy

Profuit is $-r^{\rho} K_{F}$

Sample Mean $=\left[\left(\frac{w^{o}}{1-\alpha}\right)^{1-\alpha}\left(\frac{r^{o}}{\alpha}\right)^{\alpha}\left(\frac{Q^{o}}{3}\right)\right]-\left[\frac{r^{o} K_{F}}{3}\right]$

Sample $S$ dard Deviation $=\left[\left(\frac{w^{o}}{1-\alpha}\right)^{1-\alpha}\left(\frac{r^{o}}{\alpha}\right)^{\alpha}\left(\frac{Q^{o} 3(\alpha-1)}{3 \sqrt{2}}\right)\right]-\left[\frac{\sqrt{2}\left(r^{o} K_{F}\right)}{3}\right]$

Coefficient of Variation $=\frac{1}{\sqrt{2}}\left\{\frac{\left[\left(\frac{w^{o}}{1-\alpha}\right)^{1-\alpha}\left(\frac{r^{o}}{\alpha}\right)^{\alpha}\left(\frac{Q^{o} 3(\alpha-1)}{3 \sqrt{2}}\right)\right]-\left[\frac{\sqrt{2}\left(r^{o} K_{F}\right)}{3}\right]}{\left[\left(\frac{w^{o}}{1-\alpha}\right)^{1-\alpha}\left(\frac{r^{o}}{\alpha}\right)^{\alpha}\left(\frac{Q^{o}}{3}\right)\right]-\left[\frac{r^{o} K_{F}}{3}\right]}\right\}$

\section{Comparison of Income Inequality}

Coefficient of Variation is denoted as $C V$.

$C V_{F D I}=\frac{1}{\sqrt{2}}\left(\frac{u-2 v}{t-v}\right)$

where $v=r^{o} K_{F}, \frac{u}{t}=3 \alpha-1$

$C V_{\text {closed }}=\frac{3 \alpha-1}{\sqrt{2}}=\frac{u}{t \sqrt{2}}$ 


$$
C V_{F D I}-C V_{\text {closed }}=\frac{v(u-2 t)}{t \sqrt{2}(t-v)}
$$

From $C V_{F D I}, \quad u-2 t=3 t(\alpha-1)<0$

$$
C V_{F D I}-C V_{\text {Closed }}=\frac{3(1-\alpha)}{\sqrt{2}} \cdot \frac{v}{(v-t)}
$$

The sign of the difference depends on whether $v>t$ or $t>v$.

i.e. whether $r^{o} K_{F}$ is $>$ or $<\left(\frac{w^{o}}{1-\alpha}\right)^{1-\alpha}\left(\frac{r^{o}}{\alpha}\right)^{\alpha} Q^{o}$

Simplifying R.H.S.

Since, $\left(\frac{w^{o}}{1-\alpha}\right)^{1-\alpha}\left(\frac{r^{o}}{\alpha}\right)^{\alpha}=\frac{r^{o}\left(K_{c}+K_{F}\right)}{\alpha}$

Comparng $v$ and $t$ boils down to

$r^{o} K_{F}>$ or $<\frac{r^{o}\left(K_{c}+K_{F}\right)}{\alpha}$

i.e. $K_{F}>$ or $<\frac{\left(K_{c}+K_{F}\right)}{\alpha}$

It is mathematically apparent that $\mathrm{t}$ (the term on the R.H.S.) will always be bigger. This implies that the difference between the two CVs will always be negative. Therefore, we can conclude that the income inequality in the closed economy is higher than in the open economy. 
Appendix 2: Data Dictionary, 1990-2002

\begin{tabular}{|c|c|c|}
\hline Name & Definition & Source \\
\hline $\begin{array}{l}\text { Gini } \\
\text { Personal Income } \\
\text { (Income Inequality }\end{array}$ & $\begin{array}{l}\text { The income inequality data are calculated } \\
\text { from Disposable Income. Survey includes all } \\
\text { people. The income sharing unit is the } \\
\text { household. The log of the variable is taken }\end{array}$ & $\begin{array}{l}\text { World Income Inequality } \\
\text { Database Version } 2.0 \mathrm{a}, \\
\text { June } 2005 \\
\text { Transmonee International }\end{array}$ \\
\hline $\begin{array}{l}\text { Gini } \\
\text { Gross Earnings } \\
\text { Wage Inequality }\end{array}$ & $\begin{array}{l}\text { The income inequality data are calculated } \\
\text { from Gross Earnings. Survey includes all } \\
\text { employed people. The income sharing unit is } \\
\text { the person. The log of the variable is taken. }\end{array}$ & $\begin{array}{l}\text { World Income Inequality } \\
\text { Database Version } 2.0 \mathrm{a}, \\
\text { June } 2005 \\
\text { Transmonee International }\end{array}$ \\
\hline $\begin{array}{l}\text { Foreign Direct } \\
\text { Investment as a } \\
\text { percentage of GDP }\end{array}$ & $\begin{array}{l}\text { FDI stock is the value of the share of capital } \\
\text { and reserves (including retained profits) } \\
\text { attributable to the parent enterprise, plus the } \\
\text { net indebtedness of affiliates to the parent } \\
\text { enterprise. Data on FDI stocks is presented at } \\
\text { book value or historical cost, reflecting } \\
\text { prices at the time when the investment was } \\
\text { made. Inward stock in the reporting econ- } \\
\text { omy is the value of the capital and reserves } \\
\text { in the economy attributable to a parent enter- } \\
\text { prise resident in a different economy. }\end{array}$ & $\begin{array}{l}\text { UNCTAD } \\
\text { www.unctad.org }\end{array}$ \\
\hline $\begin{array}{l}\text { GDP per capita } \\
\text { (PPP) } \\
\text { Constant } 2000 \text { US } \\
\text { Dollars }\end{array}$ & $\begin{array}{l}\text { "GDP per capita is gross domestic product } \\
\text { divided by midyear population. GDP is the } \\
\text { sum of gross value added by all resident pro- } \\
\text { ducers in the economy plus any product } \\
\text { taxes and minus any subsidies not included } \\
\text { in the value of the products. It is calculated } \\
\text { without making deductions for depreciation } \\
\text { of fabricated assets or for depletion and deg- } \\
\text { radation of natural resources. Data are in } \\
\text { constant U.S. dollars." Log of the variable is } \\
\text { taken }\end{array}$ & WDI CD-ROM 2005 \\
\hline Unemployment & $\begin{array}{l}\text { "Unemployment refers to the share of the } \\
\text { labor force that is without work but available } \\
\text { for and seeking employment. Definitions of } \\
\text { labor force and unemployment differ by } \\
\text { country. "Log of the variable is taken. }\end{array}$ & WDI CD-ROM 2005 \\
\hline $\begin{array}{l}\text { Inflation } \\
\text { GDP Deflator } \\
\text { Annual Percentage }\end{array}$ & $\begin{array}{l}\text { "Inflation as measured by the annual growth } \\
\text { rate of the GDP implicit deflator shows the } \\
\text { rate of price change in the economy as a } \\
\text { whole. The GDP implicit deflator is the ratio } \\
\text { of GDP in current local currency to GDP in } \\
\text { constant local currency". Log of the variable } \\
\text { is taken. }\end{array}$ & WDI CD-ROM 2005 \\
\hline
\end{tabular}


Appendix 2: Data Dictionary, 1990-2002

\begin{tabular}{|c|c|}
\hline Name & Definition \\
\hline $\begin{array}{l}\text { Government } \\
\text { Expenditure }\end{array}$ & $\begin{array}{l}\text { "General government final consumption } \\
\text { expenditure (formerly general government } \\
\text { consumption) includes all government cur- } \\
\text { rent expenditures for purchases of goods and } \\
\text { services (including compensation of employ- } \\
\text { ees). It also includes most expenditures on } \\
\text { national defense and security, but excludes } \\
\text { government military expenditures that are } \\
\text { part of government capital formation." It is } \\
\text { calculated as percentage of GDP. Log of the } \\
\text { variable is taken. }\end{array}$ \\
\hline
\end{tabular}

Domestic

Investment

Proportion of

Population $<=14$

Proportion of Population $>=65$

Share of Private Sector
"Gross capital formation (formerly gross domestic investment) consists of outlays on additions to the fixed assets of the economy plus net changes in the level of inventories. Fixed assets include land improvements (fences, ditches, drains, and so on); plant, machinery, and equipment purchases; and the construction of roads, railways, and the like, including schools, offices, hospitals, private residential dwellings, and commercial and industrial buildings. Inventories are stocks of goods held by firms to meet temporary or unexpected fluctuations in production or sales, and "work in progress." According to the 1993 SNA, net acquisitions of valuables are also considered capital formation." It is calculated as percentage of GDP. Log of the variable is taken

Population ages 0 to 14 is the percentage of the total population that is in the age group 0 to 14 . Log of the variable is taken

Population ages 65 and above is the percentage of the total population that is 65 or older.

"It is calculated as a percentage of GDP. The share includes income generated from the formal activities of registered private companies, as well as informal activities where reliable information is available. The term "private company" refers to all enterprises in which private individuals or entities own the majority of shares." Log of the variable is taken.
WDI CD-ROM 2005

WDI CD-ROM 2005

WDI CD-ROM 2005

EBRD Transition

Reports, 2000 and

2003 
Appendix 2: Data Dictionary, 1990-2002

\begin{tabular}{|c|c|c|}
\hline Name & Definition & Source \\
\hline $\begin{array}{l}\text { Share of Industrial } \\
\text { Sector }\end{array}$ & $\begin{array}{l}\text { "Industry corresponds to ISIC divisions 10- } \\
45 \text { and includes manufacturing (ISIC divi- } \\
\text { sions 15-37). It comprises value added in } \\
\text { mining, manufacturing (also reported as a } \\
\text { separate subgroup), construction, electricity, } \\
\text { water, and gas. Value added is the net output } \\
\text { of a sector after adding up all outputs and } \\
\text { subtracting intermediate inputs. It is calcu- } \\
\text { lated without making deductions for depreci- } \\
\text { ation of fabricated assets or depletion and } \\
\text { degradation of natural resources. The origin } \\
\text { of value added is determined by the Interna- } \\
\text { tional Standard Industrial Classification (ISIC), } \\
\text { revision 3." Log of the variable is taken. }\end{array}$ & WDI CD-ROM 2005 \\
\hline $\begin{array}{l}\text { EBRD Transition } \\
\text { Index }\end{array}$ & $\begin{array}{l}\text { Average of nine liberalization indices index } \\
\text { of price liberalization, index of forex and } \\
\text { trade liberalization, index of small-scale } \\
\text { privatization, index of large-scale privatiza- } \\
\text { tion, index of enterprise reform, index of } \\
\text { competition policy, index of banking sector } \\
\text { reform, index of non-banking sector reform } \\
\text { and index of infrastructural reform. Log of } \\
\text { the variable is taken. Varies from } 1 \text { to } 4 \text { with } \\
\text { one stands for a close economy. }\end{array}$ & $\begin{array}{l}\text { European Bank for } \\
\text { Reconstruction and } \\
\text { Development }\end{array}$ \\
\hline Political Freedom & $\begin{array}{l}\text { It is an average of two indices including } \\
\text { political rights and civil liberties. It varies } \\
\text { from one to seven with seven indicating that } \\
\text { that the country has neither of the two indi- } \\
\text { ces. Log of the variable is taken }\end{array}$ & Freedom House \\
\hline CPI & $\begin{array}{l}\text { "Consumer price index reflects changes in } \\
\text { the cost to the average consumer of acquir- } \\
\text { ing a fixed basket of goods and services that } \\
\text { may be fixed or changed at specified inter- } \\
\text { vals, such as yearly. The Laspeyres formula } \\
\text { is generally used." } 2000=100\end{array}$ & WDI CD-ROM 2005 \\
\hline
\end{tabular}


Appendix 2: Data Dictionary, 1990-2002

\begin{tabular}{|c|c|c|}
\hline Name & Definition & Source \\
\hline Services & $\begin{array}{l}\text { "Services correspond to ISIC divisions 50- } \\
99 \text { and they include value added in whole- } \\
\text { sale and retail trade (including hotels and } \\
\text { restaurants), transport, and government, } \\
\text { financial, professional, and personal services } \\
\text { such as education, health care, and real estate } \\
\text { services. Also included are imputed bank } \\
\text { service charges, import duties, and any sta- } \\
\text { tistical discrepancies noted by national com- } \\
\text { pilers as well as discrepancies arising from } \\
\text { rescaling. Value added is the net output of a } \\
\text { sector after adding up all outputs and sub- } \\
\text { tracting intermediate inputs. It is calculated } \\
\text { without making deductions for depreciation } \\
\text { of fabricated assets or depletion and degra- } \\
\text { dation of natural resources. The industrial } \\
\text { origin of value added is determined by the } \\
\text { International Standard Industrial Classifica- } \\
\text { tion (ISIC), revision } 3 \text {." It is calculated as a } \\
\text { percentage of GDP. Log of the variable is } \\
\text { taken. }\end{array}$ & WDI CD-ROM 2005 \\
\hline Average wages & $\begin{array}{l}\text { Log of the monthly earnings of all sectors in } \\
\text { an economy } \\
\text { ISIC-Rev. } 3 \text { Code }\end{array}$ & $\begin{array}{l}\text { International Labor } \\
\text { Organization } \\
\text { http://laborsta.ilo.org/ }\end{array}$ \\
\hline LNEXCHG & $\begin{array}{l}\text { Log of the Exchange Rate Local Currency } \\
\text { per US dollar }\end{array}$ & WDI CD-ROM 2005 \\
\hline Trade & $\begin{array}{l}\text { Sum of Exports and Imports as a percentage } \\
\text { of GDP }\end{array}$ & WDI Online \\
\hline $\begin{array}{l}\text { Secondary School } \\
\text { Enrollment }\end{array}$ & $\begin{array}{l}\text { Number of students enrolled in secondary } \\
\text { education as a percentage of total population }\end{array}$ & WDI Online \\
\hline $\begin{array}{l}\text { Labor Force } \\
\text { Secondary } \\
\text { Education }\end{array}$ & $\begin{array}{l}\text { Percentage of Labor with Secondary } \\
\text { Education }\end{array}$ & WDI Online \\
\hline Real Interest Rate & & WDI Online \\
\hline Productivity & GDP/Labor Force & WDI Online \\
\hline
\end{tabular}

